\title{
SPECTROSCOPIC PROPERTIES, MOLECULAR STRUCTURE, ANTICANCER AND ANTIMICROBIAL EVALUATION OF SOME NEW MOXIFLOXACIN METAL COMPLEXES IN THE PRESENCE OF 1,10-PHENANTHROLINE
}

\author{
S.M. Abd El-Hamid ${ }^{1 *}$, S.A. Sadeek ${ }^{2}$, W.A. Zordok ${ }^{2,3}$ and N.G. Rashid ${ }^{4}$ \\ ${ }^{1}$ Department of Basic Science, Higher Future Institute of Engineering and Technology, \\ Mansoura, Egypt \\ ${ }^{2}$ Department of Chemistry, Faculty of Science, Zagazig University, Zagazig, Egypt \\ ${ }^{3}$ Department of Chemistry, University College of Quanfudha, Umm Al -Qura University, KSA \\ ${ }^{4}$ Ministry of Education, Babylon, Iraq
}

(Received June 29, 2019; Revised July 22, 2020; Accepted July 28, 2020)

\begin{abstract}
New series of Y(III), Zr(IV), Pd(II), La(III) and U(VI) complexes with moxifloxacin (MOX) and 1,10-phenanthroline (Phen) were synthesized and the chelation behaviours have been investigated. The complexes were characterized using elemental analysis, molar conductance, magnetic properties, thermal studies and various spectral techniques such as FT-IR, UV-Vis, ${ }^{1} \mathrm{H}$ NMR and mass spectra. The kinetic and thermodynamic parameters $\left(\mathrm{E}^{*}, \Delta \mathrm{H}^{*}, \Delta \mathrm{S}^{*}\right.$ and $\left.\Delta \mathrm{G}^{*}\right)$ were calculated using Coats-Redfern and HorowitzMetzeger methods. The bond length and force constant, $\mathrm{F}(\mathrm{U}=\mathrm{O})$, for the uranyl complex was calculated. The DFT calculations were carried out to understand the optimized molecular geometry for the compounds. The calculated data indicated that $\mathrm{Pd}(\mathrm{II})$ complex with smaller energy gap value $(\Delta \mathrm{E}=0.136 \mathrm{au})$ is more reactive than all compounds and $\mathrm{La}(\mathrm{III})$ complex with greater energy gap $(\Delta \mathrm{E}=0.192 \mathrm{au})$ is less reactive. All studied compounds are treated as soft $(\eta=0.068-0.096)$ except MOX treated as hard $(\eta=0.16)$. The HOMO of all complexes is localized on MOX (100\%) without any density on the Phen $(0 \%)$ except $\mathrm{Pd}(\mathrm{II})$ complex, the HOMO is localized on Phen $(61 \%)$. The LUMO in U(VI) complex is localized mainly on the U(VI) ion $(63 \%)$, and in the Y(III) complex is localized mainly on Phen (89\%). The cytotoxic activities against MCF-7, HCT-116 and the antimicrobial activity were tested.
\end{abstract}

KEY WORDS: Moxifloxacin, 1,10-Phenanthroline, Spectroscopy, Thermal analysis, DFT, Antitumor agents

\section{INTRODUCTION}

Fluoroquinolones are chemotherapy agents with a fluorine atom attached to the central ring system, which represent an important class of synthetic broad-spectrum antibiotics [1]. Fluoroquinolones have high ability to coordinate with metal ions through one oxygen atom of carboxylic group and oxygen of pyridone group $[2,3]$. Thus, numerous studies regarding the interaction between fluoroquinolones with metal ions have been included in the literature [2-4]. Some of these metal complexes are more successful for their antibacterial activity than free fluoroquinolones [5-7].

Moxifloxacin hydrochloride (MOX, Scheme 1A) is a member of fluoroquinolones family, with trade names Avelox, Avalox and Avelon for oral treatment and as an ophthalmic solution (eye drops) under the trade name Vigamox for the treatment of conjunctivitis and acting as large-spectrum antibiotics, also, have anticancer activity [8-10].

The literature contains few examples, studied some mixed ligand metal complexes including fluoroquinolone with 1,10-phenanthroline monohydrate (Phen, Scheme 1B) which exhibited considerable anti-proliferative activity against HL-60 (human acute myeloid leukemia) cell lines and hormone independent BT20 breast cancer cells [11-13].

In this work, we aim to study the synthesis and characterization of $\mathrm{Y}(\mathrm{III}), \mathrm{Zr}(\mathrm{IV}), \mathrm{Pd}(\mathrm{II})$, $\mathrm{La}(\mathrm{III})$ and $\mathrm{U}(\mathrm{VI})$ complexes with MOX in the presence of Phen as N-donor heterocyclic molecule. The complexes were characterized using molar conductance, elemental analyses, melting point, magnetic susceptibility, IR spectroscopy, UV-Vis., ${ }^{1} \mathrm{H}$ NMR, mass spectra and thermal analysis (DTG and TG). DFT calculations were carried out to understand the optimized molecular geometry and energy gap $\Delta \mathrm{E}$, absolute electronegativity, $\chi$, chemical potentials, $\mathrm{Pi}$, absolute hardness, $\eta$, absolute softness, $\sigma$, global electrophilicity, $\omega$, global softness, $\mathrm{S}$, and additional electronic charge, $\Delta \mathrm{N}_{\max }$. Finally, the antimicrobial and antitumor activities for the compounds were evaluated in vitro.

*Corresponding author. E-mail: sherifmohamed266@gmail.com

This work is licensed under the Creative Commons Attribution 4.0 International License 


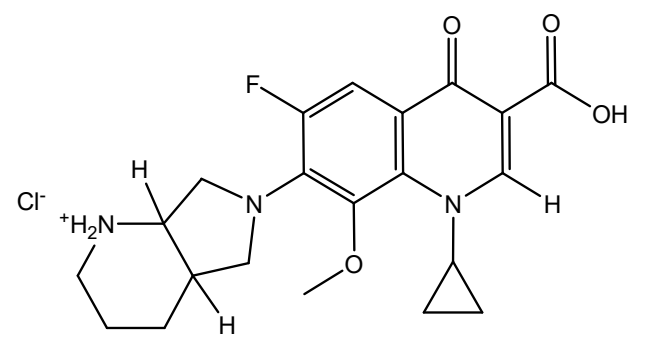

(A)

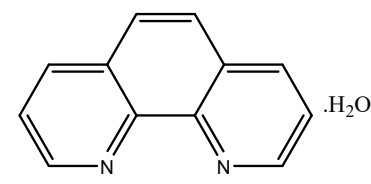

(B)

Scheme 1. (A) Structure of moxifloxacin hydrochloride (MOX) and (B) 1,10-phenanthroline monohydrate (Phen).

Chemicals

\section{EXPERIMENTAL}

All chemicals used were analytical reagent grade, commercially available from different sources and used without further purification. Moxifloxacin hydrochloride was purchased from Obour Pharmaceutical Industrial Company. 1,10-Phenanthroline monohydrate, $\mathrm{NaOH}$, ethanol, $\mathrm{FeCl}_{3} \cdot 6 \mathrm{H}_{2} \mathrm{O}, \mathrm{AgNO}_{3}, \quad \mathrm{FeSO}_{4}, \mathrm{~K}_{2} \mathrm{CrO}_{4}, \mathrm{YCl}_{3} \cdot 6 \mathrm{H}_{2} \mathrm{O}, \mathrm{ZrO}\left(\mathrm{NO}_{3}\right)_{2}, \mathrm{PdCl}_{2}, \mathrm{LaCl}_{3} \cdot 7 \mathrm{H}_{2} \mathrm{O}$ and $\mathrm{UO}_{2}\left(\mathrm{CH}_{3} \mathrm{COO}\right)_{2} \cdot 2 \mathrm{H}_{2} \mathrm{O}$ were commercial products from Fluka and Aldrich Chemical Co.

\section{Synthesis of mixed ligand metal complexes}

The pale yellow solid complex $\left[\mathrm{Y}(\mathrm{MOX})(\mathrm{Phen})\left(\mathrm{H}_{2} \mathrm{O}\right)_{2}\right] \mathrm{Cl}_{3} \cdot \mathrm{H}_{2} \mathrm{O}$, A was prepared by mixing equimolar amounts of $\mathrm{MOX}, \mathrm{NaOH}$ and Phen in $50 \mathrm{~mL}$ ethanol with $40 \mathrm{~mL}$ ethanol solution of yttrium(III) chloride hexahydrate. The reaction mixture was refluxed on a water bath for $3 \mathrm{~h}$. The precipitate was filtered off, washed with ethanol and dried in avacuum desiccator over anhydrous $\mathrm{CaCl}_{2}$. The light orange, gray, yellow and dark yellow solid complexes $\left[\mathrm{ZrO}(\mathrm{MOX})(\mathrm{Phen})\left(\mathrm{H}_{2} \mathrm{O}\right)\right]\left(\mathrm{NO}_{3}\right)_{2} \cdot 2 \mathrm{H}_{2} \mathrm{O}, \quad \mathrm{B}, \quad[\mathrm{Pd}(\mathrm{MOX})(\mathrm{Phen})] \mathrm{Cl}_{2} \cdot 3 \mathrm{H}_{2} \mathrm{O}, \quad \mathrm{C}$, $\left[\mathrm{La}(\mathrm{MOX})(\mathrm{Phen})\left(\mathrm{H}_{2} \mathrm{O}\right)_{2}\right] \mathrm{Cl}_{3} \cdot \mathrm{H}_{2} \mathrm{O}, \mathrm{D}$ and $\left[\mathrm{UO}_{2}(\mathrm{MOX})(\mathrm{Phen})\left(\mathrm{H}_{2} \mathrm{O}\right)\right]\left(\mathrm{CH}_{3} \mathrm{COO}\right)_{2} \cdot 4 \mathrm{H}_{2} \mathrm{O}, \mathrm{E}$ were prepared in a similar manner described above and using $\mathrm{ZrO}\left(\mathrm{NO}_{3}\right)_{2}, \mathrm{PdCl}_{2}, \mathrm{LaCl}_{3} .7 \mathrm{H}_{2} \mathrm{O}$ and $\mathrm{UO}_{2}\left(\mathrm{CH}_{3} \mathrm{COO}\right)_{2} \cdot 2 \mathrm{H}_{2} \mathrm{O}$.

\section{Instruments}

Carbon, hydrogen and nitrogen content of the complexes were performed using a Perkin Elmer $2400 \mathrm{CHN}$ elemental analyzer. The percentage of the metal ions was determined by using atomic absorption method pectrometer model PYE-UNICAM SP 1900 fitted with the corresponding lamp was used for this purposed and also determined gravimetrically by transforming the solid products into metal oxide. FT-IR spectra in $\mathrm{KBr}$ discs were recorded in the range from 4000-400 $\mathrm{cm}^{-1}$ with FT-IR 460 PLUS Spectrophotometer. ${ }^{1} \mathrm{H}$ NMR spectra were recorded on Varian Mercury VX-300 NMR Spectrometer using DMSO- $\mathrm{d}_{6}$ as solvent. TGA-DTG measurements were run under $\mathrm{N}_{2}$ atmosphere within the temperature range from room temperature to $1000{ }^{\circ} \mathrm{C}$ using TGA-50H Shimadzu, and the mass of sample was accurately weighted out in an aluminum crucible. Electronic spectra were obtained using UV-3101PC Shimadzu. The absorption spectra were recorded as solutions in DMSO- $\mathrm{d}_{6}$. Mass spectra were recorded on GCMS-QP-1000EX Shimadzu (ESI-70 eV) in the range from 0-1090. Magnetic susceptibilities of the powdered samples were done on a Sherwood scientific magnetic balance using Gouy balance at room temperature using $\mathrm{Hg}\left[\mathrm{Co}(\mathrm{CSN})_{4}\right]$ as calibrant. The molar conductance of $1 \times 10^{-3}$ $\mathrm{M}$ solutions of the ligands and metal complexes in DMF was measured at room temperature using CONSORT K410. All measurements were carried out with freshly prepared solutions and melting points were recorded using a Buchi apparatus.

Antimicrobial investigation

Antibacterial activity of MOX, Phen, A, B, C, D and E compounds was investigated by a previously reported modified method [14] against different bacterial species, such as 
Staphylococcus aureus, Bacillus subtilis, Escherichia coli, Pseudomonas aeruginosa and antifungal screening was studied against three species, Candida albicans, Aspergillus awamori and Alternaria species. The tested microorganisms were isolated from Egyptian soil and water. The nutrient agar medium for antibacterial was $(0.5 \%$ peptone, $0.1 \%$ beef extract, $0.2 \%$ yeast extract, $0.5 \% \mathrm{NaCl}$ and $1.5 \%$ Agar-Agar) and czapeks Dox medium for antifungal (3\% sucrose, $0.3 \% \mathrm{NaNO}_{3}, 0.1 \% \mathrm{~K}_{2} \mathrm{HPO}_{4}, 0.05 \% \mathrm{KCl}, 0.001 \% \mathrm{FeSO}_{4}, 2 \%$ Agar-Agar) was prepared [14] and then cooled to $47{ }^{\circ} \mathrm{C}$ and seeded with tested microorganisms. Sterile water agar layer was poured then solidified, the prepared growth medium for fungi and bacteria (plate of $12 \mathrm{~cm}$ diameter, $15 \mathrm{~mL}$ medium plate). After solidification $5 \mathrm{~mm}$ diameter holes were punched by a sterile cork-borer. The investigated compounds, i.e., ligands and their complexes were introduced in Petri-dishes (only $0.1 \mathrm{~mL}$ ) after dissolving in DMF at $1.0 \times 10^{-3} \mathrm{M}$. These culture plates were then incubated at $37^{\circ} \mathrm{C}$ for $20 \mathrm{~h}$ for bacteria and for seven days at $30{ }^{\circ} \mathrm{C}$ for fungi. The activity was determined by measuring the diameter of the inhibition zone (in $\mathrm{mm}$ ). Microbial growth inhibition was calculated with reference to the positive control, i.e., MOX. The activity index for the complexes was calculated [15].

\section{Anticancer activity evaluation}

The cell lines that used in this study were human breast carcinoma cell line (MCF-7 cells) and human colon carcinoma cell line (HCT-116 cells) were obtained from American Type Tissue Culture Unit. The mammalian cells were propagated in Dulbecco's Modified Eagle's Medium (DMEM) or RPMI-1640 depending on the type of cell line supplemented with $10 \%$ heatinactivated fetal bovine serum, $1 \%$ L-glutamine, HEPES buffer and $50 \mu \mathrm{g} / \mathrm{mL}$ gentamycin. All cells were maintained at $37{ }^{\circ} \mathrm{C}$ in a humidified atmosphere with $5 \% \mathrm{CO}_{2}$ and were sub cultured two times a week along experimentation.

\section{Anticancer activity evaluation using viability assay}

The extracts or pure compounds were tested against two cancer cell lines, i.e. breast carcinoma cell line (MCF-7) and colon carcinoma cell line (HCT-116). All the experiments concerning the cytotoxicity evaluation were performed and analysed by tissue culture unit at the Regional Centre for Mycology and Biotechnology RCMB, Al-Azhar University, Cairo, Egypt. Anticancer viability assay was carried according to the reported method [16]. The cancer cell lines were seeded in 96-well plate in $100 \mu \mathrm{L}$ of growth medium at a cell concentration of $1 \times 10^{4}$ cells per well. After $24 \mathrm{~h}$ of seeding, the monolayers were then washed with sterile phosphate buffered saline $(0.01 \mathrm{M}, \mathrm{pH} 7.2)$ and simultaneously the cells were treated with $100 \mu \mathrm{L}$ from different dilutions of the test sample in fresh maintenance medium and incubated at $37{ }^{\circ} \mathrm{C}$. Different twofold dilutions of the tested compound $(100,50,25,12.5,6.25,3.125,1.56$ and $0.78 \mu \mathrm{g} / \mathrm{mL}$ ) were added to confluent cell monolayers dispensed into 96-well, flat-bottomed microliter plates (Falcon, NJ, USA) using a multi channel pipette. The microliter plates were incubated at $37{ }^{\circ} \mathrm{C}$ in a humidified incubator with $5 \% \mathrm{CO}_{2}$ for a period of $24 \mathrm{~h}$. Untreated cells were served as controls. Three independent experiments were performed each containing six replicates for each concentration of the tested samples. The cytotoxic effects of the tested compounds were then measured using crystal violet staining viability assay. Briefly, after $24 \mathrm{~h}$ of treatment, the medium was removed, $100 \mu \mathrm{L}$ of $0.5 \%$ crystal violet in $50 \%$ methanol was added to each well and incubated for 20 minutes at room temperature and subsequently excess dye was washed out gently by distilled water. The plate was allowed to dry then the viable crystal violet-stained cells were lysed using 33\% glacial acetic acid solution [16]. Absorbance at $570 \mathrm{~nm}$ was then measured in each well using micro plate reader (Sun Rise, TECAN, Inc, USA). Doxorubicin was used as positive control. The absorbance is proportional to the number of surviving cells in the culture plate. Thus, using this colorimetric procedure, the tested compounds-mediated cell lyses and the cytotoxic effect of doxorubicin (used as a positive control) were measured and compared to the viability of untreated cells [17]. The stock solutions of the tested compounds were prepared in different concentrations in DMSO, DMSO alone was performed in parallel for each concentrations control.

\section{Calculation}

The percentage cell viability was calculated using the Microsoft Excel, according to the following calculation: the percentage of cell viability $=[1-(\mathrm{ODt} / \mathrm{ODc})] \times 100 \%$, where ODt is 
the mean optical density of wells treated with the tested compound and ODc is the mean optical density of untreated cells. The test compounds were compared using the $\mathrm{IC}_{50}$ value, i.e. the concentration of an individual compound leading to $50 \%$ cell death that was estimated from graphical plots of surviving cells versus compound concentrations.

\section{RESULTS AND DISCUSSION}

The prepared solid complexes of Y(III), Zr(IV), Pd(II), La(III) and U(VI) with mixed ligand (MOX and Phen) are stable in air and easily soluble in DMF and DMSO. The analytical data (Table 1) are in good agreement with the proposed molecular formulas of complexes. The molar conductance values for the complexes (144-278 S cm $\mathrm{mol}^{-1}$ ) suggest that the complexes found as 1:2 and 1:3 electrolytes [18]. Qualitative reactions revealed the presence of chloride, nitrate and acetate as counter ions in good agreement with the molar conductance data. The magnetic moments (as BM) of the complexes were measured at room temperature and have diamagnetic character and the complex of $\mathrm{Pd}(\mathrm{II})$ found as square planner [19]. The complexes were also characterized through FT-IR, UV-Vis, ${ }^{1} \mathrm{H}$ NMR and mass spectra as well as thermogravimetric analysis. The antimicrobial activities of the compounds were carried out. Also, the anticancer activity against breast carcinoma cell line (MCF-7 cells) and human colon carcinoma cell line (HCT-116 cells) was carried.

FT-IR spectroscopy can be used as a good analytical tool to follow the coordination of organic ligands with metal ions [20]. The FT-IR spectra of the MOX and Phen ligands were compared to those of the metal complexes in order to confirm the binding mode of the ligands (Table 2). The $v(\mathrm{O}-\mathrm{H})$ stretching vibration in the spectra of all complexes observed in the range $3369-3417 \mathrm{~cm}^{-1}$ is due to the presence of coordination and/or water of hydration [21].

Table 1. Elemental analysis and physico-analytical data for moxifloxacin (MOX), 1,10-phenanthroline (Phen) and their metal complexes.

\begin{tabular}{|c|c|c|c|c|c|c|c|c|}
\hline \multirow{2}{*}{$\begin{array}{l}\text { Compounds } \\
\text { M.Wt. (M.F.) }\end{array}$} & \multirow{2}{*}{$\begin{array}{c}\text { Yield } \\
\%\end{array}$} & \multirow{2}{*}{$\mathrm{Mp} /{ }^{\circ} \mathrm{C}$} & \multirow{2}{*}{ Color } & \multicolumn{4}{|c|}{ Found (Calcd.) (\%) } & \multirow{2}{*}{$\stackrel{\Lambda}{\Lambda}$} \\
\hline & & & & $\mathrm{C}$ & $\mathrm{H}$ & $\mathrm{N}$ & $\mathrm{M}$ & \\
\hline $\begin{array}{l}\text { MOX } \\
437.9\left(\mathrm{C}_{21} \mathrm{H}_{25} \mathrm{FN}_{3} \mathrm{O}_{4} \mathrm{Cl}\right)\end{array}$ & - & 240 & Yellow & \begin{tabular}{|c|}
57.59 \\
$(57.60)$
\end{tabular} & $\begin{array}{c}5.74 \\
(5.75)\end{array}$ & $\begin{array}{c}9.59 \\
(9.60)\end{array}$ & - & 33.9 \\
\hline $\begin{array}{l}\text { Phen } \\
198.2\left(\mathrm{C}_{12} \mathrm{H}_{10} \mathrm{~N}_{2} \mathrm{O}\right)\end{array}$ & - & 100 & White & $\begin{array}{c}72.70 \\
(72.72)\end{array}$ & $\begin{array}{c}5.08 \\
(5.09)\end{array}$ & $\begin{array}{c}14.12 \\
(14.13)\end{array}$ & - & 5.0 \\
\hline $\begin{array}{l}{\left[\mathrm{Y}(\mathrm{MOX})(\mathrm{Phen})\left(\mathrm{H}_{2} \mathrm{O}\right)_{2}\right] \mathrm{Cl}_{3} \cdot \mathrm{H}_{2} \mathrm{O}} \\
830.9\left(\mathrm{YC}_{33} \mathrm{H}_{38} \mathrm{FN}_{5} \mathrm{O}_{7} \mathrm{Cl}_{3}\right)\end{array}$ & 81.50 & 300 & $\begin{array}{l}\text { Pale } \\
\text { yellow }\end{array}$ & \begin{tabular}{|c|}
47.67 \\
$(47.70)$ \\
\end{tabular} & $\begin{array}{c}4.56 \\
(4.61)\end{array}$ & $\begin{array}{c}8.39 \\
(8.43)\end{array}$ & $\begin{array}{c}10.66 \\
(10.70)\end{array}$ & 278 \\
\hline $\begin{array}{l}{\left[\mathrm{ZrO}(\mathrm{MOX})(\mathrm{Phen})\left(\mathrm{H}_{2} \mathrm{O}\right)\right]\left(\mathrm{NO}_{3}\right)_{2} .2 \mathrm{H}_{2} \mathrm{O}} \\
866.9\left(\mathrm{ZrC}_{33} \mathrm{H}_{38} \mathrm{FN}_{7} \mathrm{O}_{14}\right)\end{array}$ & 71.00 & 296 & $\begin{array}{l}\text { Light } \\
\text { orange }\end{array}$ & $\begin{array}{c}45.68 \\
(45.72)\end{array}$ & $\begin{array}{c}4.39 \\
(4.42)\end{array}$ & $\begin{array}{c}11.28 \\
(11.31) \\
\end{array}$ & $\begin{array}{c}10.48 \\
(10.52) \\
\end{array}$ & 144 \\
\hline $\begin{array}{l}{[\mathrm{Pd}(\mathrm{MOX})(\mathrm{Phen})] \mathrm{Cl}_{2} .3 \mathrm{H}_{2} \mathrm{O}} \\
813\left(\mathrm{PdC}_{33} \mathrm{H}_{38} \mathrm{FN}_{5} \mathrm{O}_{7} \mathrm{Cl}_{2}\right)\end{array}$ & 85.00 & 281 & Gray & $\begin{array}{c}48.71 \\
(48.75)\end{array}$ & $\begin{array}{c}4.67 \\
(4.71)\end{array}$ & $\begin{array}{c}8.58 \\
(8.61)\end{array}$ & $\begin{array}{c}13.07 \\
(13.09)\end{array}$ & 196 \\
\hline $\begin{array}{l}{\left[\mathrm{La}(\mathrm{MOX})(\mathrm{Phen})\left(\mathrm{H}_{2} \mathrm{O}\right)_{2}\right] \mathrm{Cl}_{3} \cdot \mathrm{H}_{2} \mathrm{O}} \\
880.9\left(\mathrm{LaC}_{33} \mathrm{H}_{38} \mathrm{FN}_{5} \mathrm{O}_{7} \mathrm{Cl}_{3}\right)\end{array}$ & 78.50 & 344 & Yellow & $\begin{array}{c}44.93 \\
(44.99)\end{array}$ & $\begin{array}{c}4.31 \\
(4.35)\end{array}$ & $\begin{array}{c}7.93 \\
(7.95)\end{array}$ & \begin{tabular}{c|c|}
15.75 \\
$(15.77)$
\end{tabular} & 275 \\
\hline $\begin{array}{l}{\left[\mathrm{UO}_{2}(\mathrm{MOX})(\mathrm{Phen})\left(\mathrm{H}_{2} \mathrm{O}\right)\right]\left(\mathrm{CH}_{3} \mathrm{COO}\right)_{2} .4 \mathrm{H}_{2} \mathrm{O}} \\
1059.8\left(\mathrm{UC}_{37} \mathrm{H}_{48} \mathrm{FN}_{5} \mathrm{O}_{15}\right)\end{array}$ & 75.34 & 277 & $\begin{array}{c}\text { Dark } \\
\text { yellow }\end{array}$ & $\begin{array}{c}41.87 \\
(41.93)\end{array}$ & $\begin{array}{c}4.54 \\
(4.57)\end{array}$ & $\begin{array}{c}6.56 \\
(6.61)\end{array}$ & $\begin{array}{c}22.42 \\
(22.46)\end{array}$ & 167 \\
\hline
\end{tabular}

\section{FT-IR absorption spectroscopy}

The infrared spectrum of MOX showed a strong band at $1709 \mathrm{~cm}^{-1}$ which attributed to the stretching vibration of $v(\mathrm{C}=\mathrm{O})_{\text {carb }}$ of its carboxylic group (-COOH) [22]. The spectra of the five complexes showed two characteristic bands in the ranges of $1619-1623 \mathrm{~cm}^{-1}$ and $1347-1377$ $\mathrm{cm}^{-1}$, which assigned to asymmetric and symmetric stretching vibrations of $v\left(\mathrm{COO}^{-}\right)$, respectively, of MOX. The frequency difference $\Delta v$ for our complexes above $200 \mathrm{~cm}^{-1}$, this indicates that the carboxylate group is probably bound in a monodentate fashion [23]. The strong band observed at $1622 \mathrm{~cm}^{-1}$ in the spectrum of MOX is assigned to $v(\mathrm{C}=\mathrm{O})_{\mathrm{py}}$ vibration, this peak is shifted to a lower value in the range $1558-1568 \mathrm{~cm}^{-1}$ for the spectra of complexes indicating decrease in the stretching force constant of the $\mathrm{C}=\mathrm{O}$ bond as consequence of the coordination of the oxygen atom to the metal ions [24].

The absorption band found at $\sim 1586 \mathrm{~cm}^{-1}$ in the spectrum of Phen attributed to $v(\mathrm{C}=\mathrm{N})$ and the shift of this band to lower frequency region $\left(63-69 \mathrm{~cm}^{-1}\right)$ in all complexes indicate the coordination of the pyridine nitrogen atoms of Phen to the metal ions and this can be explained by the donation of lone pair of electrons from nitrogen to the empty d-orbital of the metal ion in a bidentate fashion [25]. 
The $v(\mathrm{M}-\mathrm{O})$ and $v(\mathrm{M}-\mathrm{N})$ bands are found in the spectra of the complexes at 652,554 and $502 \mathrm{~cm}^{-1}$ for A complex, at $656,547,492$ and $437 \mathrm{~cm}^{-1}$ for B complex, at 541, 489 and $432 \mathrm{~cm}^{-1}$ for $\mathrm{C}$ complex, at 653,551 and $500 \mathrm{~cm}^{-1}$ for $\mathrm{D}$ complex and at $669,618,551$ and $500 \mathrm{~cm}^{-1}$ for $\mathrm{E}$ complex, these bands are absent in the spectra of free MOX and Phen.

The FT-IR spectra showed that $v(\mathrm{Zr}=\mathrm{O})$ found as a medium band at $811 \mathrm{~cm}^{-1}$ and $v_{\mathrm{as}}(\mathrm{U}=\mathrm{O})$ and $v_{\mathrm{s}}(\mathrm{U}=\mathrm{O})$ absorption bands occur as a very strong singlet at $912 \mathrm{~cm}^{-1}$ and medium at $816 \mathrm{~cm}^{-1}$, respectively [26]. The proposed structures for complexes are represented in Scheme 2. The $v(\mathrm{U}=\mathrm{O})$ of the uranyl unit in $\mathrm{E}$ complex found at lower frequency values compared with those in simple salt. The $v_{s}(U=O)$ value was used to calculate both the bond length and the bond stretching force constant, $\mathrm{F}(\mathrm{U}=\mathrm{O})$, for $\mathrm{UO}_{2}$ bond in our complex [27]. The calculated bond length and force constant values are $1.750 \AA$ and 644.20 $\mathrm{Nm}-1$, respectively.

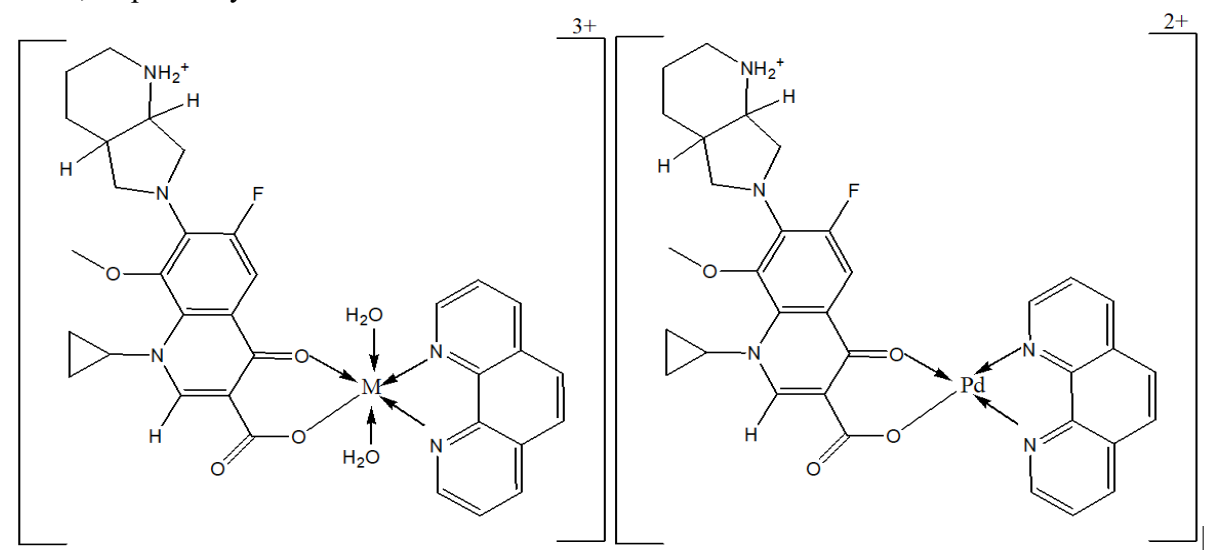

The proposed structure for $\mathrm{M}=\mathrm{Y}(\mathrm{III})$ and $\mathrm{La}(\mathrm{III})$

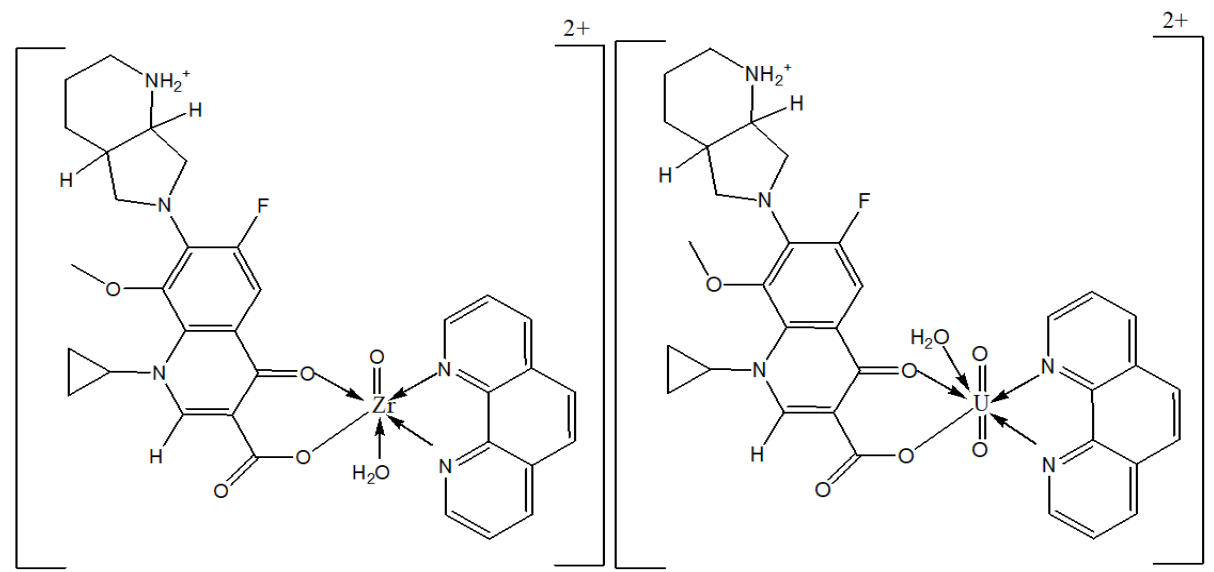

Scheme 2. The coordination mode of Y(III), Zr(IV), Pd(II), La(III) and U(VI) with MOX and Phen.

\section{Electronic spectroscopy}

The electronic absorption spectra of the investigated ligands and their metal complexes in DMSO- $\mathrm{d}_{6}$ were scanned in the wavelength range $200-800 \mathrm{~nm}$ (Figure 1). Free MOX showed two bands at 257 and $298 \mathrm{~nm}$ assigned to $\pi-\pi^{*}$ and $n-\pi^{*}$ transitions, respectively [28]. Also, Phen showed bands at 273 and $350 \mathrm{~nm}$ which due to $\pi-\pi^{*}$ and $n-\pi^{*}$ transitions [29]. The absorption spectra for A, B, C, D and E complexes are practically identical with that of free ligands, some shifted of the bands to lower or higher values were observed which indicative of chelation through the donor atoms of the ligands [30]. Also, the five complexes showed a group of new 
bands in the range 524-560 nm, which may be assigned to the ligand to metal charge-transfer $(\mathrm{L} \rightarrow \mathrm{M})$. The slightly distorted square planer $\mathrm{C}$ complex exhibited a d-d transition band at 653 $\mathrm{nm}$ which may be assigned to $\mathrm{d}_{\mathrm{z}}^{2} \longrightarrow \mathrm{d}_{\mathrm{x}-\mathrm{y}}^{2}{ }^{2}$ transition [20].

Table 2. Selected infrared absorption frequencies $\left(\mathrm{cm}^{-1}\right)$ of ligands and their complexes.

\begin{tabular}{|c|c|c|c|c|c|c|c|c|c|}
\hline compounds & $\begin{array}{c}v(\mathrm{O}-\mathrm{H}) \\
\mathrm{H}_{2} \mathrm{O} ; \\
\mathrm{COOH}\end{array}$ & $\begin{array}{c}v(\mathrm{C}=\mathrm{O}) \\
\mathrm{COOH}\end{array}$ & $v_{\text {as }}\left(\mathrm{COO}^{-}\right)$ & $\begin{array}{l}v(\mathrm{C}=\mathrm{O}), \\
\text { pyridone } \\
\text { group }\end{array}$ & $v(\mathrm{C}=\mathrm{N})$ & $v_{\mathrm{s}}\left(\mathrm{COO}^{-}\right)$ & $\begin{array}{c}v_{\mathrm{as}}(\mathrm{U}=\mathrm{O}) \\
\text { and } \\
v_{\mathrm{s}}(\mathrm{U}=\mathrm{O})\end{array}$ & $v(\mathrm{Zr}=\mathrm{O})$ & $\begin{array}{c}v(\mathrm{M}-\mathrm{O}) \text { and } \\
v(\mathrm{M}-\mathrm{N})\end{array}$ \\
\hline MOX & $3472(\mathrm{~m})$ & 1709 (s) & - & 1622(vs) & - & - & - & - & - \\
\hline Phen & $\begin{array}{l}3380 \\
(\mathrm{mbr})\end{array}$ & - & - & - & $1586(\mathrm{~ms})$ & - & - & - & - \\
\hline $\begin{array}{c}\mathrm{Y}(\mathrm{MOX})(\mathrm{Phen}) \\
\left.\left(\mathrm{H}_{2} \mathrm{O}\right)_{2}\right] \mathrm{Cl}_{3} \cdot \mathrm{H}_{2} \mathrm{O}\end{array}$ & $\begin{array}{l}3369 \\
(\mathrm{mbr})\end{array}$ & - & $1620(\mathrm{vs})$ & $1568(\mathrm{~m})$ & 1523(w) & $1350(\mathrm{~m})$ & - & - & $\begin{array}{c}\text { 652(m), 554(vw), } \\
502(\mathrm{w})\end{array}$ \\
\hline $\begin{array}{l}\mathrm{ZrO}(\mathrm{MOX})(\mathrm{Phen}) \\
\left.\left(\mathrm{H}_{2} \mathrm{O}\right)\right]\left(\mathrm{NO}_{3}\right)_{2} \cdot 2 \mathrm{H}_{2} \mathrm{O}\end{array}$ & $\begin{array}{l}3414 \\
(\mathrm{mbr})\end{array}$ & - & $1623(\mathrm{~s})$ & $1565(\mathrm{~ms})$ & $1520(\mathrm{~ms})$ & $1377(\mathrm{~m})$ & - & $811(\mathrm{~m})$ & $\begin{array}{c}656(\mathrm{w}), 547(\mathrm{vw}) \\
492(\mathrm{w}), 437(\mathrm{vw})\end{array}$ \\
\hline $\begin{array}{c}\mathrm{Pd}(\mathrm{MOX})(\text { Phen })] \\
\mathrm{Cl}_{2} .3 \mathrm{H}_{2} \mathrm{O}\end{array}$ & $\begin{array}{l}3408 \\
(\mathrm{mbr})\end{array}$ & - & 1619 (vs) & $1565(\mathrm{~ms})$ & $1519(w)$ & $1347(\mathrm{~m})$ & - & - & $\begin{array}{c}\text { 541(vw), 489(w), } \\
432(\mathrm{vw})\end{array}$ \\
\hline $\begin{array}{c}\mathrm{La}(\mathrm{MOX})(\mathrm{Phen}) \\
\left.\left(\mathrm{H}_{2} \mathrm{O}\right)_{2}\right] \mathrm{Cl}_{3} \cdot \mathrm{H}_{2} \mathrm{O}\end{array}$ & $\begin{array}{l}3384 \\
(\mathrm{mbr})\end{array}$ & - & $1619(\mathrm{~s})$ & $1563(\mathrm{~m})$ & $1522(w)$ & $1350(\mathrm{~m})$ & - & - & $\begin{array}{c}653(\mathrm{vw}), 551(\mathrm{vw}), \\
500(\mathrm{w})\end{array}$ \\
\hline $\begin{array}{c}\mathrm{UO}_{2}(\mathrm{MOX})(\mathrm{Phen}) \\
\left.\left(\mathrm{H}_{2} \mathrm{O}\right)\right]\left(\mathrm{CH}_{3} \mathrm{COO}\right)_{2} . \\
4 \mathrm{H}_{2} \mathrm{O}\end{array}$ & $\begin{array}{l}3417 \\
(\mathrm{mbr})\end{array}$ & - & $1619(\mathrm{~m})$ & $1558(\mathrm{~m})$ & $1517(\mathrm{~m})$ & $1350(\mathrm{~m})$ & $\begin{array}{l}912(\mathrm{vs}) \\
816(\mathrm{~m})\end{array}$ & - & $\begin{array}{c}669(\mathrm{~ms}), 618(\mathrm{vw}, \\
551(\mathrm{vw}), 500(\mathrm{~m})\end{array}$ \\
\hline
\end{tabular}

Keys: $\mathrm{s}=$ strong, $\mathrm{w}=$ weak, $\mathrm{m}=$ medium, $\mathrm{br}=$ broad.
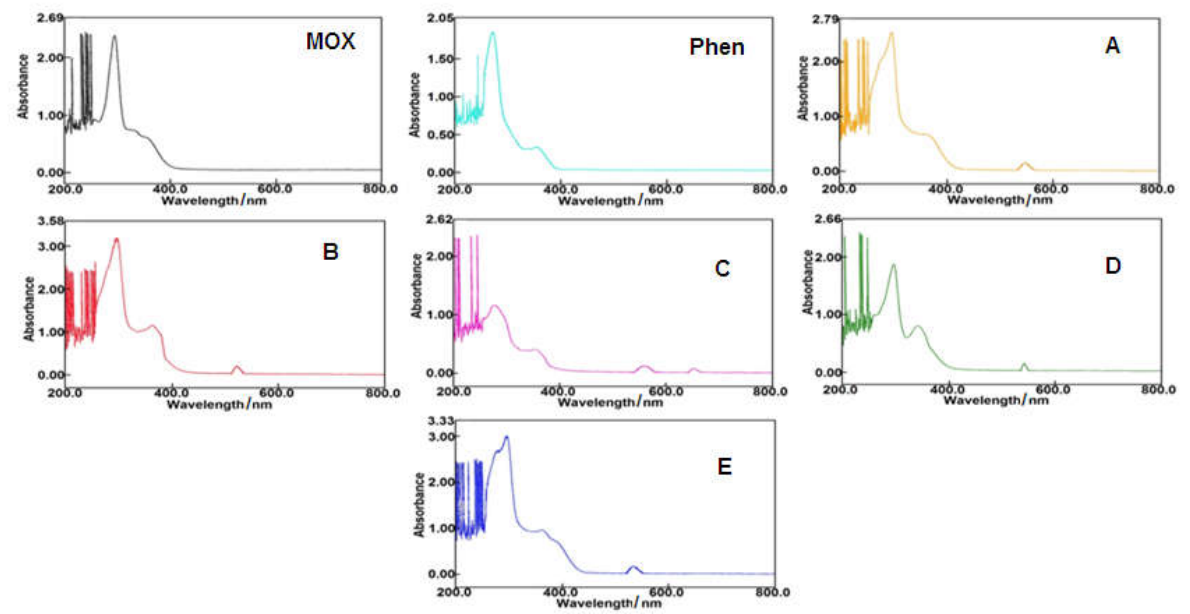

Figure 1. Electronic absorption spectra for MOX, Phen, A, B, C, D and E.

${ }^{1} H$ NMR spectroscopy

The ${ }^{1} \mathrm{H}$ NMR spectra of MOX, Phen and their metal complexes were recorded in dimethylsulfoxide (DMSO- $\mathrm{d}_{6}$ ) in the range 0-14 ppm using tetramethylsilane (TMS) as internal standard (Figure 2). The spectrum of MOX showed the following signals: $\left(\delta \mathrm{H},-\mathrm{CH}_{2}\right.$ and $-\mathrm{CH}$ cyclopropane) at $0.28-1.35 \mathrm{ppm}$ range, $\left(\delta \mathrm{H},-\mathrm{CH}_{2}\right.$ bicyclic ring) at $1.38-3.6 \mathrm{ppm}$ range, $(\delta \mathrm{H}$, $\mathrm{OCH}_{3}$ methoxy $)$ at $3.73 \mathrm{ppm},\left(\delta \mathrm{H},-\mathrm{NH}_{2}^{+}\right)$at $7.00 \mathrm{ppm},(\delta \mathrm{H},-\mathrm{CH}$ aromatic $)$ at range of $6.68-$ 7.96 ppm range. Also, the ${ }^{1} \mathrm{H}$ NMR spectrum of Phen showed peaks in the range at $\delta: 7.26-8.81$ $\mathrm{ppm}$ for the protons of aromatic ring. The new signals which not detected in the spectrum of the free ligands and appeared in the range $\delta: 3.85-4.30 \mathrm{ppm}$ can be assigned to the water molecules [31]. Upon comparison with the free MOX ligand, the signal observed at $11.0 \mathrm{ppm}$ which assigned to the carboxylate proton [32] and disappeared in the spectra of all complexes confirmed that MOX chelated with the metal ions under proton displacement. All peaks of the free ligands are present in spectra of the complexes with some shifts from binding of the ligand to the metal ions [33]. 


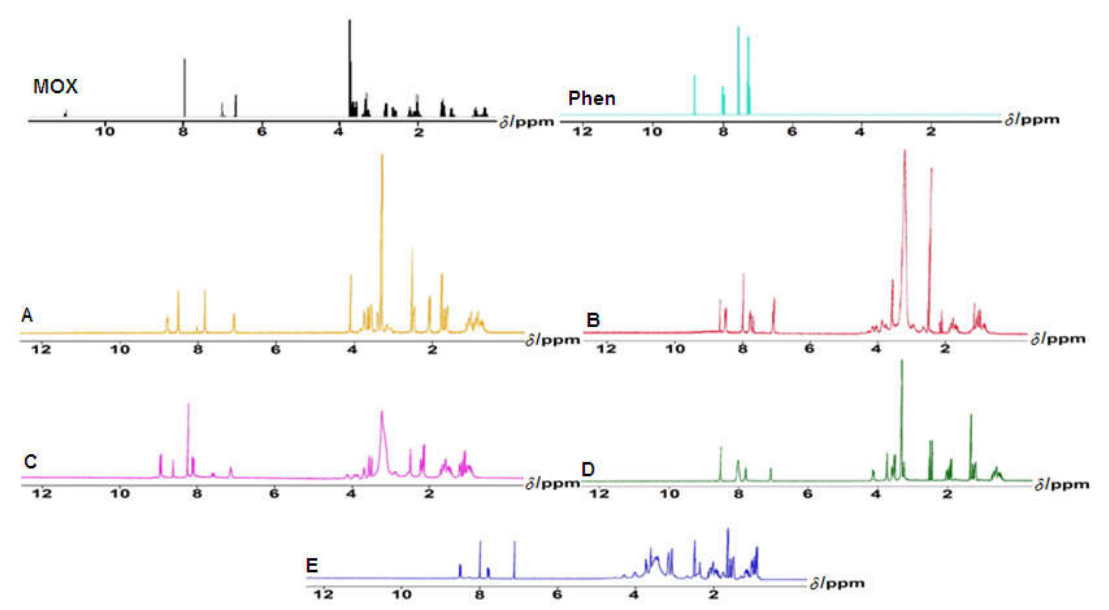

Figure 2. ${ }^{1} \mathrm{H}$ NMR spectra for MOX, Phen, A, B, C, D and E.

Mass spectroscopy

The mass spectra of the complexes provide good evidence for the molecular formulas. The mass spectra of A, B, C, D and E complexes displayed molecular peaks at $\mathrm{m} / \mathrm{z}$ (\%) 829 (41\%), 866 $(20 \%), 812(42 \%), 879(28 \%)$ and $1059(24 \%)$, respectively, which agree well with the formula's weights. The fragmentation pattern and mass spectrum of E complex as representative example, is depicted in Scheme 3. The molecular ion peak [a] appeared at $\mathrm{m} / \mathrm{z}=1059(24 \%)$ loses $\mathrm{C}_{15} \mathrm{H}_{28} \mathrm{~N}_{2} \mathrm{O}_{5}$ to give [b] at $\mathrm{m} / \mathrm{z}=743(25.19 \%)$ and it loses $\mathrm{C}_{7} \mathrm{H}_{14} \mathrm{~N}_{2}$ to give [c] at $\mathrm{m} / \mathrm{z}=933$ (25.69\%). The molecular ion peak [a] loses $\mathrm{C}_{8} \mathrm{H}_{22} \mathrm{FO}_{9}$ to give [d] at $\mathrm{m} / \mathrm{z}=778(22.42 \%)$ and it loses $\mathrm{C}_{4} \mathrm{H}_{10} \mathrm{FO}_{6}$ to give [e] at $\mathrm{m} / \mathrm{z}=886(19.90 \%)$. The molecular ion peak [a] loses $\mathrm{C}_{7} \mathrm{H}_{22} \mathrm{~N}_{2} \mathrm{O}_{4}$ to give fragment [f] at $\mathrm{m} / \mathrm{z}=861(16.37 \%)$ and it loses $\mathrm{C}_{15} \mathrm{H}_{30} \mathrm{~N}_{2} \mathrm{O}_{6}$ to give fragment $[\mathrm{g}] \mathrm{at} \mathrm{m} / \mathrm{z}=$ $725(15.11 \%)$.

\section{Thermal analysis}

Thermogravimetric analyses (TGA and DTG) of ligands and their metal complexes were recorded (Figure 3). The TG of the isolated complexes was taken as a proof for the existing of the water molecules as well as the anions to be inside or outside the coordination sphere. The heating rate was suitably controlled at $10{ }^{\circ} \mathrm{C} \mathrm{min}^{-1}$ with rate flow $30 \mathrm{~mL} \mathrm{~min}{ }^{-1}$. The thermal analysis of MOX found in literature [34] which showed that MOX is stable up to $260{ }^{\circ} \mathrm{C}$ and melts at $240{ }^{\circ} \mathrm{C}$ and decomposed in one step. The thermal degradation of Phen takes place in two degradation stages. The first stage occurs at $95{ }^{\circ} \mathrm{C}$ maximum and is accompanied by a weight loss of $8.02 \%$. The second decomposition stage occurs at maximum $278{ }^{\circ} \mathrm{C}$ with a weight loss of $91.98 \%$ corresponding to loss of $5 \mathrm{C}_{2} \mathrm{H}_{2}+\mathrm{C}_{2} \mathrm{~N}_{2}$ [35].

The TGA and DTG curves of A complex showed three stages of decomposition. The first step of decomposition in the temperature range $40-190^{\circ} \mathrm{C}$ with weight loss of $2.38 \%$ (calc. $=$ $2.17 \%$ ) corresponds to loss of hydrated water molecule. The second step occurs within temperature range $190-359{ }^{\circ} \mathrm{C}$ with a weight loss $26.32 \%$ may attributed to the liberation of coordinated water molecules with Phen. The third step is reasonably accounted for the organic MOX ligand with estimated weight loss $54.92 \%$. The total weight loss $83.62 \%$ (calc. $=83.52 \%$ ) up to $1000{ }^{\circ} \mathrm{C}$ is in agreement with the formation $\mathrm{YO}_{1.5}+2 \mathrm{C}$ as a final residue.

The $\mathrm{B}$ complex decomposed gradually with the formation of zirconium oxide above $870{ }^{\circ} \mathrm{C}$ in three steps as indicated by DTG peaks around $40-60{ }^{\circ} \mathrm{C}, 60-285{ }^{\circ} \mathrm{C}$ and $285-870{ }^{\circ} \mathrm{C}$, corresponding to the weight loss of two lattice water molecules, coordinated water molecules with Phen and $10 \mathrm{C}_{2} \mathrm{H}_{2}+\mathrm{HF}+\mathrm{NH}_{3}+\mathrm{CO}+4 \mathrm{NO}_{2}$, respectively.

The thermal decomposition of $\mathrm{C}$ complex takes place in three steps in the ranges $42-88{ }^{\circ} \mathrm{C}$, $88-417{ }^{\circ} \mathrm{C}$ and $417-943{ }^{\circ} \mathrm{C}$, respectivly, corresponding to loss of two lattice water molecules, one water molecule with Phen and MOX molecule, respectively, giving palladium oxide as a final residue. The thermal decomposition of $\mathrm{D}$ complex occurs in three degradation steps. The Bull. Chem. Soc. Ethiop. 2020, 34(2) 
first stage occurs at $50{ }^{\circ} \mathrm{C}$ with a weight loss of $2.13 \%$, corresponding to loss of hydrated water molecules. The second decomposition stage occurs at $136{ }^{\circ} \mathrm{C}$ with a weight loss of $24.56 \%$ and the third stage occurs at 332,571 and $869^{\circ} \mathrm{C}$ associated to the loss of MOX molecule.

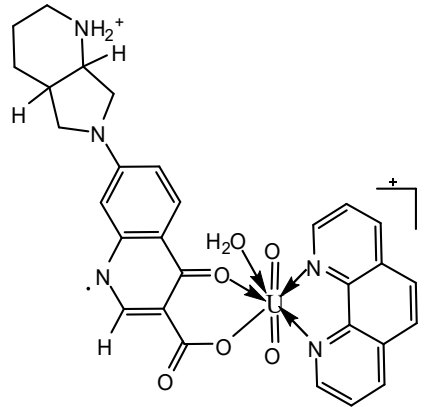

[d] $778(22.42 \%)$
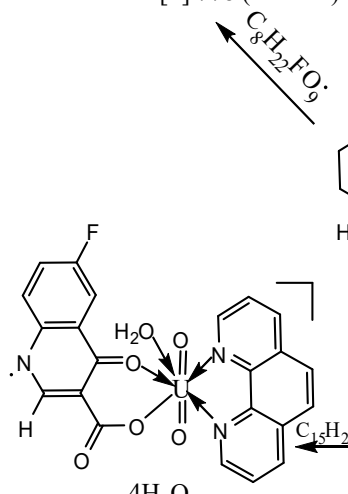

$.4 \mathrm{H}_{2} \mathrm{O}$

[b] $743(25.19 \%)$<smiles>C[C@H]1NCCCC1(C)C</smiles>

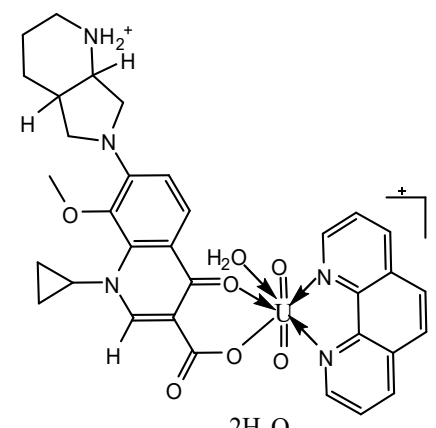

[e] $886(19.90 \%)$

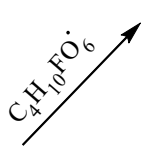

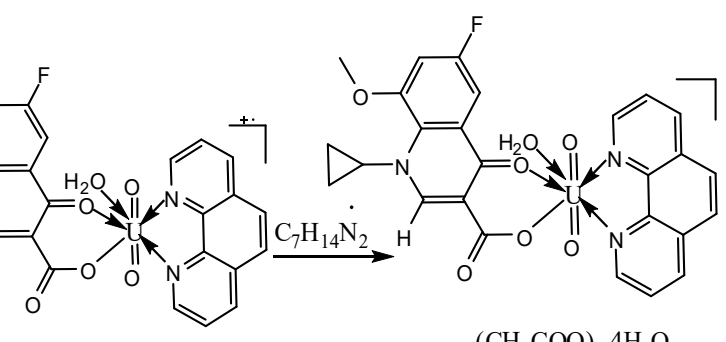
$\left(\mathrm{CH}_{3} \mathrm{COO}\right)_{2} \cdot 4 \mathrm{H}_{2} \mathrm{O}$

$\left(\mathrm{CH}_{3} \mathrm{COO}\right)_{2} \cdot 4 \mathrm{H}_{2} \mathrm{O}$ [a] m/z $1059(24 \%)$

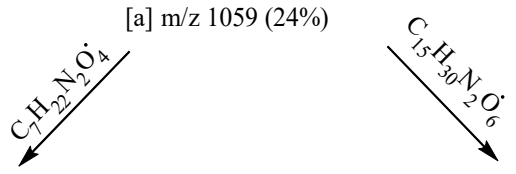

[c] $933(25.69 \%)$

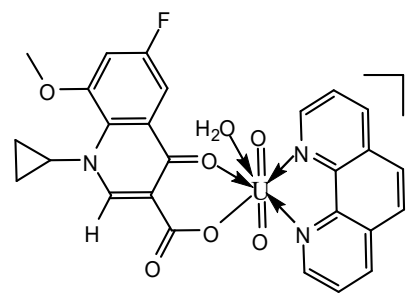

$\left(\mathrm{CH}_{3} \mathrm{COO}\right)_{2}$ [f] $861(16.37 \%)$

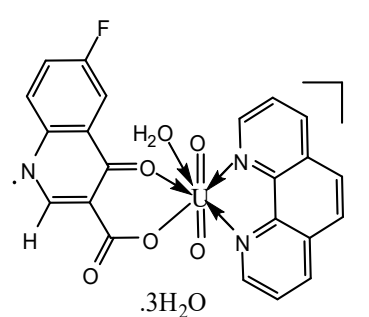

[g] $725(15.11 \%)$

Scheme 3. Fragmentation pattern of E complex.

The hydrated E complex loses four hydrated water molecules in the first step within the temperature range of $42-80{ }^{\circ} \mathrm{C}$. The second step occurs at 165,211 and $255^{\circ} \mathrm{C}$ is associated to the loss of coordinated water and Phen. The third step occurs at 366 and $532^{\circ} \mathrm{C}$ with loss of MOX forming $\mathrm{UO}_{2}+4 \mathrm{C}$ as a final product. The weight for the residue after decomposition is $30.60 \%$ giving an actual total weight loss of $69.40 \%$ in agreement with our calculated total weight loss values of $69.99 \%$. The above going mechanisms were also supported by the infrared spectra of the final decomposition products which showed the absence of all bands associated to MOX and Phen and the characteristic bands of metal oxides are appeared. 


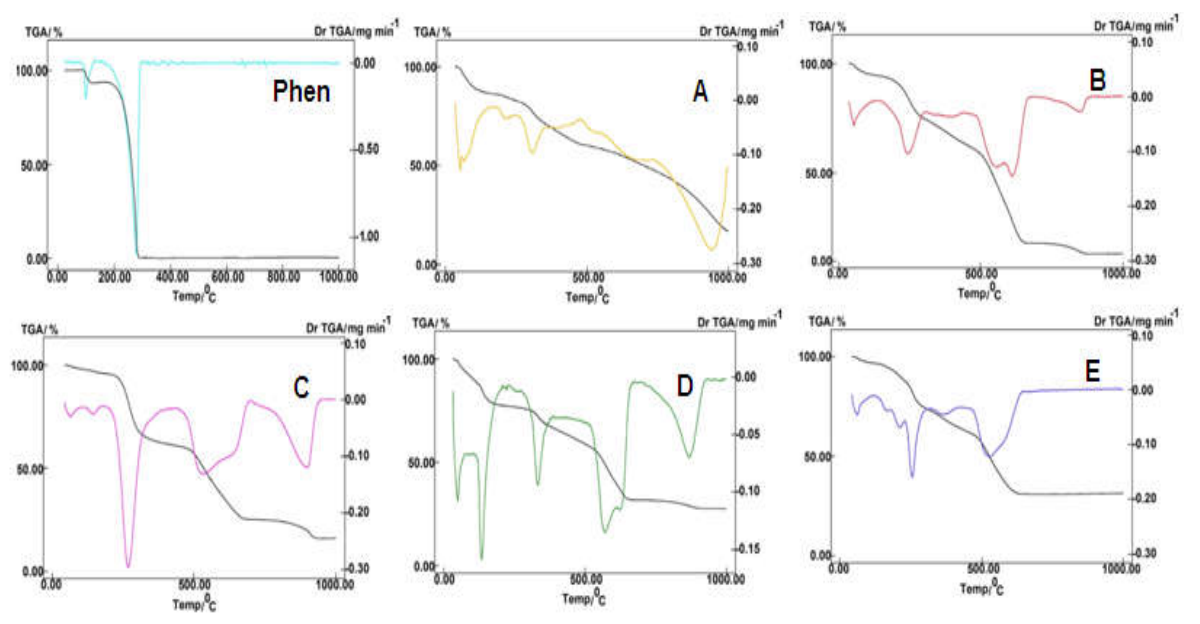

Figure 3. TGA and DTG diagrams for Phen, A, B, C, D and E.

Table 3. Thermal behavior and kinetic parameters determined using Coats-Redfern (CR) and HorowitzMetzger (HM) operated for MOX, Phen and their metal complexes.

\begin{tabular}{|c|c|c|c|c|c|c|c|c|c|c|}
\hline \multirow[b]{2}{*}{ Compounds } & \multirow[b]{2}{*}{$\begin{array}{c}\text { Decomposition } \\
\text { Range }(\mathrm{K})\end{array}$} & \multirow[b]{2}{*}{$\begin{array}{c}\mathrm{T}_{\mathrm{s}} \\
(\mathrm{K})\end{array}$} & \multirow[b]{2}{*}{ method } & \multicolumn{5}{|c|}{ parameter } & \multirow[b]{2}{*}{$\mathrm{R}^{\mathrm{a}}$} & \multirow[b]{2}{*}{$\mathrm{SD}^{\mathrm{b}}$} \\
\hline & & & & $\begin{array}{c}\mathrm{E}^{*} \\
(\mathrm{KJ} / \mathrm{mol})\end{array}$ & $\begin{array}{c}\mathrm{A} \\
\left(\mathrm{s}^{-1}\right)\end{array}$ & $\begin{array}{c}\Delta \mathrm{S}^{*} \\
(\mathrm{~kJ} / \mathrm{mol} . \mathrm{K})\end{array}$ & $\begin{array}{c}\Delta \mathrm{H}^{*} \\
(\mathrm{~kJ} / \mathrm{mol})\end{array}$ & $\begin{array}{c}\Delta \mathrm{G}^{*} \\
(\mathrm{~kJ} / \mathrm{mol})\end{array}$ & & \\
\hline \multirow{2}{*}{$\begin{array}{c}(\mathrm{MOX}) \\
\left(\mathrm{C}_{21} \mathrm{H}_{25} \mathrm{FN}_{3} \mathrm{O}_{4} \mathrm{Cl}\right)\end{array}$} & \multirow[t]{2}{*}{$525-602$} & \multirow[t]{2}{*}{563} & CR & 182.33 & $2.40 \times 10^{12}$ & -0.0132 & 177.65 & 185.08 & 0.997 & 0.082 \\
\hline & & & HM & 135.64 & $3.30 \times 10^{10}$ & -0.0488 & 130.96 & 158.45 & 0.996 & 0.097 \\
\hline \multirow{2}{*}{$\begin{array}{c}\text { Phen } \\
\left(\mathrm{C}_{12} \mathrm{H}_{10} \mathrm{~N}_{2} \mathrm{O}\right)\end{array}$} & \multirow[t]{2}{*}{$394-572$} & \multirow[t]{2}{*}{551} & $\mathrm{CR}$ & 117.83 & $2.03 \times 10^{9}$ & -0.0718 & 113.25 & 152.84 & 0.996 & 0.120 \\
\hline & & & HM & 146.78 & $7.97 \times 10^{11}$ & -0.0222 & 142.20 & 154.42 & 0.998 & 0.076 \\
\hline \multirow{4}{*}{$\begin{array}{c}\mathrm{A} \\
\left(\mathrm{YC}_{33} \mathrm{H}_{38} \mathrm{FN}_{5} \mathrm{O}_{7} \mathrm{Cl}_{3}\right)\end{array}$} & \multirow[t]{2}{*}{$313-353$} & \multirow[t]{2}{*}{326} & $\mathrm{CR}$ & 96.13 & $1.71 \times 10^{12}$ & -0.0115 & 93.42 & 97.16 & 0.997 & 0.067 \\
\hline & & & HM & 93.18 & $2.75 \times 10^{11}$ & -0.0267 & 90.47 & 99.17 & 0.998 & 0.058 \\
\hline & \multirow[t]{2}{*}{$529-632$} & \multirow[t]{2}{*}{580} & CR & 115.61 & $1.05 \times 10^{8}$ & -0.0969 & 110.79 & 167.00 & 0.997 & 0.067 \\
\hline & & & HM & 128.74 & $3.02 \times 10^{9}$ & -0.0689 & 123.92 & 163.92 & 0.998 & 0.060 \\
\hline \multirow{4}{*}{$\begin{array}{c}\mathrm{B} \\
\left(\mathrm{ZrC}_{33} \mathrm{H}_{38} \mathrm{FN}_{7} \mathrm{O}_{14}\right)\end{array}$} & \multirow[t]{2}{*}{$313-366$} & \multirow[t]{2}{*}{323} & CR & 78.81 & $1.22 \times 10^{10}$ & -0.0 & 76.13 & 93.07 & 0.995 & 0.083 \\
\hline & & & HM & 81.57 & $2.44 \times 10^{11}$ & -0.0276 & 78.88 & 87.79 & 0.996 & 0.084 \\
\hline & \multirow[t]{2}{*}{$366-559$} & \multirow[t]{2}{*}{515} & $\mathrm{CR}$ & 62.56 & $8.04 \times 10^{3}$ & -0.1747 & 58.27 & 148.24 & 0.996 & 0.110 \\
\hline & & & HM & 79.18 & $6.44 \times 10^{5}$ & -0.1382 & 74.90 & 146.10 & 0.997 & 0.106 \\
\hline \multirow{4}{*}{$\frac{\mathrm{C}}{\left(\mathrm{PdC}_{33} \mathrm{H}_{38} \mathrm{FN}_{5} \mathrm{O}_{7} \mathrm{Cl}_{2}\right)}$} & \multirow[t]{2}{*}{$465-690$} & \multirow[t]{2}{*}{543} & CR & 114.33 & $1.83 \times 10^{8}$ & -0.0917 & 109.82 & 159.63 & 0.996 & 0.076 \\
\hline & & & $\mathrm{HM}$ & 117.91 & $1.77 \times 10^{9}$ & -0.0729 & 113.40 & 152.96 & 0.997 & 0.075 \\
\hline & \multirow[t]{2}{*}{$986-1216$} & 117 & $\mathrm{CR}$ & 215.64 & $1.18 \times 10^{7}$ & -0.1209 & 205.88 & 347.68 & 0.998 & 0.051 \\
\hline & & 3 & $\mathrm{HM}$ & 247.09 & $3.63 \times 10^{8}$ & & 237.34 & 345.76 & 0.999 & 0.040 \\
\hline \multirow{6}{*}{$\begin{array}{c}\mathrm{D} \\
\left(\mathrm{LaC}_{33} \mathrm{H}_{38} \mathrm{FN}_{5} \mathrm{O}_{7} \mathrm{Cl}_{3}\right)\end{array}$} & \multirow[t]{2}{*}{$327-449$} & \multirow[t]{2}{*}{409} & CR & 33.40 & 71.44 & -0.2120 & 29.99 & 116.72 & 0.998 & 0.049 \\
\hline & & & HM & 42.85 & $1.52 \times 10^{3}$ & -0.1866 & 39.45 & 115.77 & 0.998 & 0.059 \\
\hline & $449-634$ & 605 & CR & 51.93 & 74.25 & -0.2150 & 46.90 & 176.96 & 0.998 & 0.052 \\
\hline & & & HM & 71.60 & $5.97 \times 10^{3}$ & -0.1785 & 66.57 & 174.57 & 0.998 & 0.063 \\
\hline & $931-1182$ & 114 & $\mathrm{CR}$ & 211.38 & $1.89 \times 10^{7}$ & -0.1167 & 201.88 & 335.21 & 0.999 & 0.039 \\
\hline & & 2 & $\mathrm{HM}$ & 245.26 & $6.24 \times 10^{8}$ & -0.0877 & 235.77 & 335.93 & 0.999 & 0.027 \\
\hline $\mathrm{E}$ & $316-429$ & 334 & $\mathrm{CR}$ & 36.90 & $1.16 \times 10^{3}$ & -0.1872 & 34.13 & 96.65 & 0.996 & 0.073 \\
\hline$\left(\mathrm{UC}_{37} \mathrm{H}_{48} \mathrm{FN}_{5} \mathrm{O}_{15}\right)$ & & & HM & 33.44 & $1.02 \times 10^{3}$ & -0.1883 & 30.66 & 93.54 & 0.997 & 0.070 \\
\hline & $501-560$ & 527 & $\mathrm{CR}$ & 131.39 & $5.52 \times 10^{10}$ & -0.0440 & 127.01 & 150.20 & 0.998 & 0.061 \\
\hline & & & HM & 141.31 & $1.04 \times 10^{12}$ & -0.0196 & 136.93 & 147.27 & 0.998 & 0.066 \\
\hline
\end{tabular}

$\mathrm{a}=$ correlation coefficients of the Arrhenius plots and $\mathrm{b}=$ standard deviation.

The kinetic and thermodynamic parameters of the compounds such as, activation energies, $E^{*}$, enthalpies, $\Delta H^{*}$, entropies, $\Delta S^{*}$ and Gibbs free energies, $\Delta G^{*}$, were calculated using CoatsRedfern (CR) and Horowitz-Metzeger (HM) methods and listed in Table $3[36,37]$. The negative values of $\Delta \mathrm{S}^{*}$ for the degradation process indicate that more ordered activated complex than the reactants or the reaction is slow which indicate a more ordered activated state that may possible be through the chemisorption of oxygen and other decomposition products. The positive values for $\Delta \mathrm{H}^{*}$ indicate the endothermic behavior for all decomposition processes. The positive sign of $\Delta G^{*}$ reveals that the free energy of the final residue is higher than that of the initial compound, and hence all the decomposition steps are non-spontaneous processes. The correlation coefficient of the Arrhenius plots of the thermal decomposition steps were found to 
lie in the range 0.995 to 0.999 , showing a good fit with linear function. The high values of $E^{*}$ reflect the thermal stability of the complexes and also indicate that the processes involving in translational, rotational, vibrational states and changes in mechanical potential energy for complexes.

\section{Pharmacology}

The MOX, Phen and their metal complexes were evaluated for antimicrobial activity against Gram positive, Gram negative bacteria and fungi. The zone of inhibition was measured in $\mathrm{mm}$ and the values of the investigated compounds are summarized in Table 4.

Table 4. The inhibition diameter zone values (mm) for MOX, Phen and their metal complexes.

\begin{tabular}{|c|c|c|c|c|c|c|c|c|c|c|c|c|c|c|}
\hline \multirow{3}{*}{$\begin{array}{c}\text { Tested } \\
\text { compounds }\end{array}$} & \multicolumn{14}{|c|}{ Microbial species } \\
\hline & \multicolumn{8}{|c|}{ Bacteria } & \multicolumn{6}{|c|}{ Fungi } \\
\hline & E. coli & AI & \begin{tabular}{|c|}
$P$. \\
aerugin \\
osa
\end{tabular} & $\mathrm{AI}$ & \begin{tabular}{|c|} 
B. \\
subtilis
\end{tabular} & $\mathrm{AI}$ & \begin{tabular}{|c|}
$S$. \\
aureus
\end{tabular} & AI & $\begin{array}{c}C . \\
\text { albican } \\
s\end{array}$ & $\mathrm{AI}$ & \begin{tabular}{|c|}
$A$. \\
awamori
\end{tabular} & $\mathrm{AI}$ & $\begin{array}{c}\text { Alternaria } \\
s p .\end{array}$ & $\mathrm{AI}$ \\
\hline MOX & \begin{tabular}{|c|}
23 \\
\pm 0.25 \\
\end{tabular} & - & \begin{tabular}{|c|}
21 \\
\pm 0.02 \\
\end{tabular} & - & $\begin{array}{c}37 \\
\pm 0.11 \\
\end{array}$ & - & $\begin{array}{c}42 \\
\pm 0.17 \\
\end{array}$ & - & \begin{tabular}{|c|}
20 \\
\pm 0.07 \\
\end{tabular} & - & 0 & 0 & 0 & 0 \\
\hline Phen & \begin{tabular}{|c|}
29 \\
\pm 0.33
\end{tabular} & 1.26 & $\begin{array}{c}30 \\
\pm 0.16 \\
\end{array}$ & 1.43 & $\begin{array}{c}38 \\
\pm 0.34 \\
\end{array}$ & 1.03 & \begin{tabular}{|c|}
28 \\
\pm 0.10 \\
\end{tabular} & 0.67 & \begin{tabular}{|c|}
35 \\
\pm 0.27 \\
\end{tabular} & 1.75 & 0 & 0 & 0 & 0 \\
\hline A & $\begin{array}{c}28^{+1} \\
\pm 1.40\end{array}$ & 1.22 & $\begin{array}{c}22^{\mathrm{NS}} \\
\pm 0.53\end{array}$ & 1.05 & $\begin{array}{c}40^{+1} \\
\pm 0.78\end{array}$ & 1.08 & \begin{tabular}{|c|}
41 \\
\pm 0.20 \\
\end{tabular} & 0.98 & \begin{tabular}{|c|}
19 \\
\pm 0.17 \\
\end{tabular} & 0.95 & 0 & 0 & 0 & 0 \\
\hline B & $\begin{array}{c}24^{\mathrm{NS}} \\
\pm 0.33\end{array}$ & 1.04 & $\begin{array}{c}24^{\mathrm{NS}} \\
\pm 1.22\end{array}$ & 1.14 & $\begin{array}{c}47^{+2} \\
\pm 0.87\end{array}$ & 1.27 & \begin{tabular}{|c|}
$45^{+1}$ \\
\pm 0.66
\end{tabular} & 1.07 & $\begin{array}{c}18 \\
\pm 0.26\end{array}$ & 0.90 & 0 & 0 & 0 & 0 \\
\hline $\mathrm{C}$ & \begin{tabular}{|c|}
22 \\
\pm 0.40
\end{tabular} & 0.96 & $\begin{array}{c}20 \\
\pm 0.31\end{array}$ & 0.95 & $\begin{array}{c}44^{+1} \\
\pm 1.69\end{array}$ & 1.19 & \begin{tabular}{|c|}
$43^{\mathrm{NS}}$ \\
\pm 0.41
\end{tabular} & 1.02 & $\begin{array}{c}10 \\
\pm 0.50\end{array}$ & 0.5 & 0 & 0 & 0 & 0 \\
\hline $\mathrm{D}$ & $\begin{array}{c}27^{+1} \\
\pm 1.12\end{array}$ & 1.17 & $\begin{array}{c}27^{+1} \\
\pm 1.13\end{array}$ & 1.29 & $\begin{array}{c}39^{\mathrm{NS}} \\
\pm 0.73\end{array}$ & 1.05 & \begin{tabular}{|c|}
40 \\
\pm 0.27 \\
\end{tabular} & 0.95 & $\begin{array}{c}21^{\mathrm{NS}} \\
\pm 0.38 \\
\end{array}$ & 1.05 & 0 & 0 & 0 & 0 \\
\hline $\mathrm{E}$ & \begin{tabular}{|c|}
$30^{+1}$ \\
\pm 0.96 \\
\end{tabular} & 1.30 & $\begin{array}{c}23^{\mathrm{NS}} \\
\pm 0.82 \\
\end{array}$ & 1.10 & $\begin{array}{c}46^{+2} \\
\pm 0.66 \\
\end{array}$ & 1.24 & $\begin{array}{c}50^{+2} \\
\pm 0.18 \\
\end{array}$ & 1.19 & $\begin{array}{c}25^{+1} \\
\pm 0.92 \\
\end{array}$ & 1.25 & 0 & 0 & 0 & 0 \\
\hline $\mathrm{YCl}_{3} \cdot 6 \mathrm{H}_{2} \mathrm{O}$ & 0 & 0 & 0 & 0 & 0 & 0 & $\begin{array}{c}10 \\
\pm 0.1 \\
\end{array}$ & 0.24 & 0 & 0 & 0 & 0 & 0 & 0 \\
\hline $\mathrm{ZrO}\left(\mathrm{NO}_{3}\right)_{2}$ & 0 & 0 & 0 & 0 & 0 & 0 & 0 & 0 & 0 & 0 & 0 & 0 & 0 & 0 \\
\hline $\mathrm{PdCl}_{2}$ & $\begin{array}{c}9 \\
\pm 0.73 \\
\end{array}$ & 0.39 & 0 & 0 & $\begin{array}{c}5 \\
\pm 0.52 \\
\end{array}$ & 0.14 & 0 & 0 & 0 & 0 & 0 & 0 & 0 & 0 \\
\hline $\mathrm{LaCl}_{3} .7 \mathrm{H}_{2} \mathrm{O}$ & \begin{tabular}{|l|}
0 \\
\end{tabular} & 0 & 0 & 0 & 0 & 0 & 0 & 0 & 0 & 0 & 0 & 0 & 0 & 0 \\
\hline $\begin{array}{c}\mathrm{UO}_{2}\left(\mathrm{CH}_{3} \mathrm{COO}\right)_{2} . \\
2 \mathrm{H}_{2} \mathrm{O}\end{array}$ & 0 & 0 & 0 & 0 & 0 & 0 & 0 & 0 & 0 & 0 & 0 & 0 & 0 & 0 \\
\hline Control (DMF) & 0 & 0 & 0 & 0 & 0 & 0 & 0 & 0 & 0 & 0 & 0 & 0 & 0 & 0 \\
\hline
\end{tabular}

$<0.01 ; \mathrm{P}^{+3} \mathrm{P}$ very highly significant, $\mathrm{P}<0.001$; student's $t$-test (Paired). $\mathrm{AI}=$ Activity index.

\section{Antimicrobial activity}

The efficiencies of MOX, Phen and their metal complexes were investigated with E. coli, $P$. aeruginosa as Gram negative, B. subtilis, S. Aureus as Gram positive and C. Albicans, A. awamori, Alternariaas fungi species. The activity of the complexes has been compared with a common standard antibiotic MOX and the antibacterial resulted that most of metal complexes showed high activity against both Gram negative and Gram positive bacteria's. This enhancement in the activity can be explained on the basis of chelation theory [38]. From the observed results, ligands and metal complexes showed no antifungal activity except $C$. Albicans.

The E complex $\left(46^{+2}\right.$ and $50^{+2}$ ) possess highly significant against $B$. subtilis and $S$. Aureus, also, B $\left(47^{+2}\right)$ complex shows highly significant against $B$. subtilis compared with MOX. The activity index of the complexes was compared with the activity index of a common standard MOX and the data showed the highest activity for $\mathrm{E}$ complex $\left(30^{+1}\right)$ against $E$. coli.

In general, the increasing of antimicrobial activities are as follows: (i) the presence of uncoordinated groups that permits the recognition by living organism and enhances the solubility (hydrophilic or hydrophobic), (ii) the ability to form hydrogen bonding with a counter anion or solvent molecules, (iii) the dimension and nature of the substituted groups attached to the donor atoms that influence the MOX ligand lipophilicity and membrane permeability, controlling thus the cell penetration, (iv) the small coordination number or the presence of some ligands easy to be removed in interaction with biomolecules, (v) a stereochemistry that allows a favorable three dimensional interaction with biomolecules and (vi) a high kinetic and 
thermodynamic stability in order to control the dissociation in the acidic medium from the stomach, the metabolization in sanguine flux and to induce a low substitution rate with the biomolecules [39].

\section{Anticancer activity evaluation}

The in vitro cytotoxicity's of MOX, Phen and their metal complexes were evaluated with human breast carcinoma cell line (MCF-7 cells) and human colon carcinoma cell line (HCT-116 cells) by crystal violet staining viability assay. The concentration which showed $50 \%\left(\mathrm{IC}_{50}\right)$ inhibition of the cell viability was analyzed by linear fitting.

Figure 4 showed that MOX have inhibitory activities with $\mathrm{IC}_{50}$ values of 17.2 and 17.8 $\mu \mathrm{g} / \mathrm{mL}$ against breast and colon carcinoma cells, respectively. The tested compounds showed high inhibitory activities against a human breast carcinoma (MCF-7) cell line. The highest detected inhibitory activity was measured for U(VI) complex followed by B, D and A complexes with $\mathrm{IC}_{50}$ values of $5.58,7.54,8.21$ and $11.5 \mu \mathrm{g} / \mathrm{mL}$, respectively. Similarly, the tested compounds showed high inhibitory activities against a human colon carcinoma (HCT116) cell line. The A complex shows the strongest ability to inhibit the growth of human colon carcinoma cell line followed by $\mathrm{B}$, then $\mathrm{E}$ with $\mathrm{IC}_{50}$ values of $5.13,8.58$ and $9.20 \mu \mathrm{g} / \mathrm{mL}$, respectively. It was interesting to note that Phen showed higher inhibition activity and lower $\mathrm{IC}_{50}$ as compared with its metal complexes (Figure 4). Thus, these complexes are considered as agent with potential anti-tumor activity and can therefore be candidate for further stages of screening in vitro and/or in vivo.

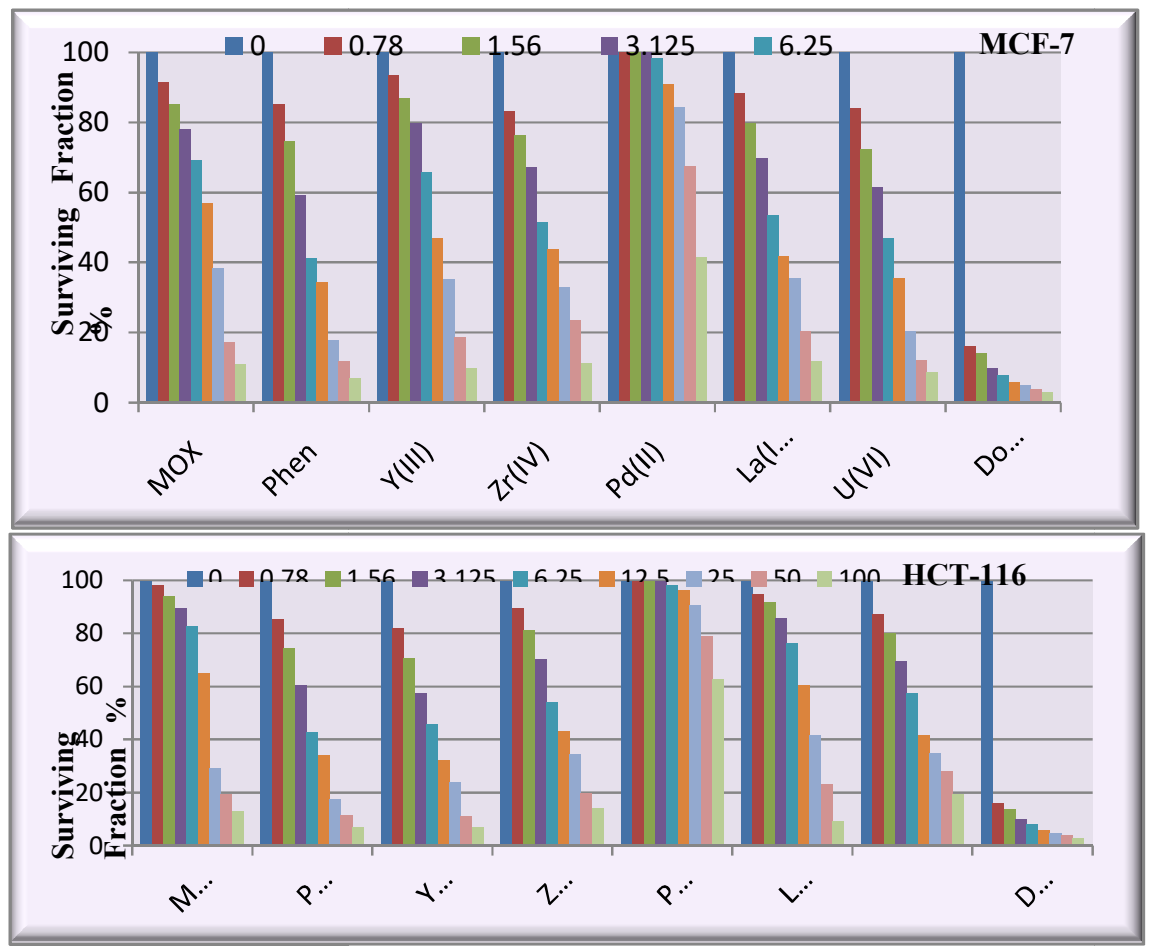

Figure 4. The dose response curve showing the in vitro inhibitory activity of the tested compounds against (A) human breast carcinoma (MCF-7) and (B) human colon carcinoma (HCT-116) cell lines.

\section{Computational studies}

The equilibrium geometry of the compounds was investigated by DFT calculations at the B3LYP/CEP-31G level of the theory, using the GAUSSIAN 98W package of the programs [40] along with the B3LYP functional and Lee Yang Parr's correlation functional. The StuttgartDresden [41] basis set and effective core potential (ECP) were applied for the lanthanum and uranium atoms. 
Geometrical structure of moxifloxacin

The values of dihedral angles are neither zero nor $180^{\circ}$ which indicated that the molecule is a highly sterically-hindered and the terminal bi-cyclic group is out of plane of the molecule. Figure 5 shows the optimized geometrical structure of MOX molecule, the dihedral angles $\mathrm{O} 1 \mathrm{C} 2 \mathrm{C} 3 \mathrm{C} 24$ and $\mathrm{O} 25-\mathrm{C} 24-\mathrm{C} 3-\mathrm{C} 2$ confirm a cis configuration of $\mathrm{O} 1$ and $\mathrm{O} 25$. While, the angle $\mathrm{O} 23-\mathrm{C} 24-\mathrm{C} 3-\mathrm{C} 2\left(176.2^{\circ}\right)$ indicate that $\mathrm{O} 23$ and $\mathrm{O} 1$ are in trans configuration and $\mathrm{C} 24-\mathrm{O} 25$ in the same plane with $\mathrm{C} 2-\mathrm{O} 1$. Also, the methyl and cyclopropyl groups found out of plane of the molecule. The value of bond angle $\mathrm{C} 2-\mathrm{C} 3-\mathrm{C} 24$ is $122.01^{\circ}$ which reflects a sp ${ }^{2}$ hybridization of $\mathrm{C} 3$, the same result is obtained with $\mathrm{C} 2$ and $\mathrm{C} 24$. The values of bond length are compared with that obtained from X-ray data [11]. Charge distribution on the optimized geometry of MOX significant built up of charge density on the oxygen atoms which distributed over all molecule so MOX behaves as bi-dentate ligand through $\mathrm{O}_{\mathrm{pyr}}$ and $\mathrm{O}_{\text {carb }}$ atoms with dipole $\mu=4.35$ and 250.42 au energy value.

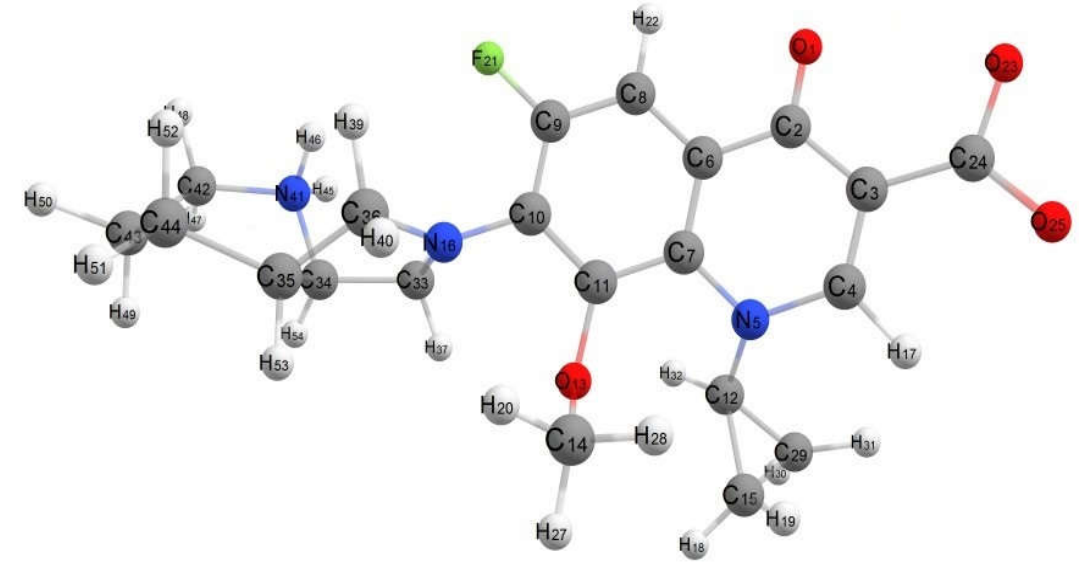

Figure 5. Optimized geometrical structure of MOX by using DFT calculations.

\section{Geometrical structure of complexes}

The MO-treatment has been applied to investigate the geometrical parameters and structural properties of $\mathrm{A}, \mathrm{B}, \mathrm{C}, \mathrm{D}$ and $\mathrm{E}$ complexes.

\section{Structure of A complex}

The bond length between Y(III) and nitrogen atoms of Phen (N7 and N10) are 2.587 and 2.609 $\AA$, respectively (Table 5) and the bond length between central Y(III) and oxygen atoms of MOX $\left(\mathrm{O}_{\text {pyr }}\right.$ and $\left.\mathrm{O}_{\text {carb }}\right)$ are 2.441 and $2.389 \AA$ [42], also, the bond length between $\mathrm{Y}(\mathrm{III})$ and oxygen atoms of water molecules (O11 and $\mathrm{O} 12)$ are 2.352 and $2.357 \AA$. The bond length of $\mathrm{C}-\mathrm{O}$ in A complex is shorter than that in the free ligand, the $\mathrm{C} 2-\mathrm{O} 1$ and $\mathrm{C} 4-\mathrm{O} 5$ are 1.211 and $1.348 \AA$. The angles around the Y(III) ion varied from $66.68^{\circ}$ to $170.09^{\circ}$, these values different largely from regular octahedron.

The equatorial plane is occupied by four atoms, two oxygen atoms of MOX, one oxygen atom of water molecule and one nitrogen atom of Phen. The axial plane is occupied by two atoms, nitrogen atom of Phen and oxygen atom of water molecule, and the values of bond angles proved that the two ligand molecules not laying the same plane but they are perpendicular to each other with the two water molecules lying in cis form. The total energy of A complex is $-417.1803 \mathrm{au}$, and the heat of formation is $-15293.478 \mathrm{kcal} / \mathrm{mol}$ and the greater dipole moment 20.12D, value attributed to chelate of MOX and Phen with Y(III).

\section{Structure of B complex}

The B complex is treated as distorted octahedral structure. The equatorial plane consists of two oxygen atoms of MOX, one nitrogen atom of Phen and one oxygen atom of $\mathrm{ZrO}$ group and the 
axial plane is occupied by one nitrogen atom of Phen and oxygen atom of water molecule. The bond length angles and charge accumulated on coordinated atoms found in Table 5 [43].

Table 5. Equilibrium geometric parameters bond lengths $(\AA)$, bond angles $\left(^{\circ}\right)$, total energy (au), heat of formation $(\mathrm{kcal} / \mathrm{mol})$ and dipole moment (D) of A, B, C, D and E complexes by using DFT calculations.

\begin{tabular}{|c|c|c|c|c|c|}
\hline Bond lengths $(\AA)$ & $\mathrm{A}$ & $\mathrm{B}$ & $\mathrm{C}$ & $\mathrm{D}$ & $\mathrm{E}$ \\
\hline M-O1 & 2.441 & 2.207 & 2.012 & 2.495 & 2.234 \\
M-O5 & 2.389 & 2.109 & 1.985 & 2.299 & 2.191 \\
M-N7 & 2.587 & 2.312 & 1.975 & 2.742 & 2.558 \\
M-N10 & 2.609 & 2.318 & 1.983 & 2.753 & 2.561 \\
M-O11 & 2.352 & 2.011 & - & 2.449 & 1.786 \\
M-O12 & 2.357 & 2.132 & - & 2.451 & 1.794 \\
M-O13 & - & - & - & - & 2.518 \\
C2-O1 & 1.211 & 1.211 & 1.212 & 1.212 & 1.221 \\
C2-C3 & 1.365 & 1.364 & 1.359 & 1.365 & 1.358 \\
C3-C4 & 1.366 & 1.365 & 1.359 & 1.366 & 1.345 \\
C4-O5 & 1.348 & 1.348 & 1.346 & 1.347 & 1.333 \\
C4-O6 & 1.212 & 1.213 & 1.211 & 1.212 & 1.213 \\
N7-C8 & 1.271 & 1.271 & 1.269 & 1.272 & 1.277 \\
C8-C9 & 1.355 & 1.353 & 1.351 & 1.356 & 1.344 \\
C9-N10 & 1.271 & 1.271 & 1.269 & 1.272 & 1.265 \\
\hline O1-M-O5 & 80.64 & 87.22 & 93.80 & 78.18 & 72.29 \\
O1-M-N7 & 83.11 & 91.20 & 91.20 & 82.20 & 84.45 \\
O1-M-N10 & 86.13 & 85.31 & 170.60 & 84.81 & 143.01 \\
O1-M-O11 & 83.89 & 176.02 & - & 82.63 & 99.22 \\
O1-M-O12 & 170.09 & 85.59 & - & 168.28 & 78.13 \\
O5-M-N7 & 159.66 & 100.64 & 168.90 & 155.47 & 154.32 \\
O5-M-N0 & 99.98 & 168.69 & 94.60 & 98.37 & 136.66 \\
O5-M-O11 & 81.06 & 93.69 & - & 82.73 & 92.71 \\
O5-M-O12 & 103.02 & 83.21 & - & 105.39 & 92.06 \\
N7-M-N10 & 66.68 & 71.07 & 80.4 & 65.07 & 69.01 \\
N7-M-O11 & 109.31 & 92.43 & - & 109.31 & 80.16 \\
N7-M-O12 & 91.19 & 174.88 & - & 91.19 & 93.68 \\
N10-M-O11 & 169.67 & 94.34 & - & 166.88 & 100.99 \\
N10-M-O12 & 84.17 & 104.63 & - & 83.63 & 78.37 \\
O11-M-O12 & 105.69 & 90.67 & - & 108.78 & 173.54 \\
O1-M-O13 & - & - & - & - & 131.78 \\
O5-M-O13 & - & - & - & - & 60.63 \\
N7-M-O13 & - & - & - & - & 143.26 \\
N10-M-O13 & - & - & - & - & 80.11 \\
O11-M-O13 & - & - & - & - & 86.92 \\
O12-M-O13 & - & - & - & - & 99.26 \\
\hline Total energy, au & -417.183 & -437.287 & -407.107 & -598.891 & -765.836 \\
Heat of formation, kcal/mol & -15293.478 & -15204.986 & -15622.173 & -16394.024 & -16727.005 \\
Total dipole moment, D & 20.12 & 38.68 & 27.59 & 28.13 & 14.39 \\
\hline & \multicolumn{5}{|c}{} \\
\hline
\end{tabular}

The angles around $\mathrm{Zr}(\mathrm{IV})$ with surrounding oxygen and nitrogen atoms varied from $71.07^{\circ}$ to $176.02^{\circ}$; these values agree well with distorted octahedron and the atoms O1, O5, N10 and $\mathrm{O} 11$ are lying in the equatorial plane, with the axial plane is occupied by two atoms, N7 and O12 of water molecule and the two ligands (MOX and phen) not lying in the same plane and lying in two perpendicular plans. The oxygen atom (O11) of $\mathrm{ZrO}$ is lying in trans to oxygen atom (O1) of MOX and in cis position to oxygen atom (O12) of water molecule. The calculated energy heat of formation and the dipole moment is greater than other all complexes. The greater value of dipole moment attributed to presence of oxygen atom of $\mathrm{ZrO}$ group which replaced by $\mathrm{H}_{2} \mathrm{O}$ on other complexes.

\section{Structure of C complex}

The C complex consisting of palladium center with slightly distorted square planer geometry. The two ligands form two chelate rings with $\mathrm{Pd}(\mathrm{II})$ one six membered ring and second five membered ring. The Pd-N length is shorter than Pd-O length as reported $\mathrm{Pd}(\mathrm{II})$ complexes. The 
bond length between $\mathrm{Pd}(\mathrm{II})$ and surrounded oxygen atoms $\mathrm{O} 1$ and $\mathrm{O} 5$ of MOX are 2.012 and $1.985 \AA$ [44], while that for Pd(II) with N7 and N10 are 1.975 and $1.983 \AA$ (Table 5). The bond angles around $\mathrm{Pd}(\mathrm{II})$ ion agree with slightly distorted square planer structure. The $\mathrm{Pd}(\mathrm{II})$ is bonded strongly with oxygen atoms of MOX more than nitrogen atoms of Phen, with the charge accumulated on $\mathrm{O} 1$ and $\mathrm{O} 5$ are -0.303 and -0.334 , while that on N7 and N10 are -0.026 and -0.052 . The calculated energy, heat of formation and the dipole moment found in Table 5.

\section{Structure of D complex}

The D complex exists as distorted octahedral structure with the angles varied from $65.07^{\circ}$ to $168.28^{\circ}$ and the two ligands (MOX and Phen) are lying perpendicular to each other. The equatorial plane is occupied by $\mathrm{O} 1$ and $\mathrm{O} 5$ of MOX, N7 of Phen and $\mathrm{O} 12$ of one water molecule. The remaining coordinated atoms, N10 of and O11 of second water molecule are located in the axial position, with the bond angle N10-La-O11 is $166.88^{\circ}$. The bond angles values of O5-La-N7, O1-La-O12 and O11-La-O12 are $155.47^{\circ}, 168.28^{\circ}$ and $108.78^{\circ}$, respectively, which confirm the two water molecules located in cis position respect to each other. The bond length between La(III) and oxygen atoms of MOX, nitrogen atoms of Phen and oxygen atoms of the water molecules are listed in Table 5 [45]. From the charge accumulated data on oxygen atoms (O1 and O5) and nitrogen atoms (N7 and N10), the $\mathrm{La}(\mathrm{III})$ is bonded strongly with oxygen atoms of MOX more than nitrogen atoms of Phen. The calculated energy, heat of formation and the dipole moment found in Table 5.

\section{Structure of E complex}

The U(VI) is seven coordinates with slightly distorted pentagonal bipyramidal. The equatorial plane consisted of O1,O5 (MOX), N7, N10 (Phen) with the bond angles O5-U-N10 and $\mathrm{O} 1-\mathrm{U}-\mathrm{N} 7$ are $136.66^{\circ}$ and $84.45^{\circ}$ and $\mathrm{O} 13$ atom of water molecule with the axial position occupy by two oxygen of $\mathrm{UO}_{2}$ unit. The $\mathrm{U}=\mathrm{O}$ length in the uranyl fragment found in the expected range 1.786-1.794 and the uranyl moiety is slightly bent with bond angle O11-U-O12, $173.54^{\circ}$. The U-N bond length of the Phen found in the range 2.558 to $2.561 \AA$ [46] (Table 5), and the U-O length of the MOX (O1 and O5) lie in the range 2.234 to $2.191 \AA$, which confirm that the oxygen atoms are coordinated to $\mathrm{U}(\mathrm{VI})$ more strongly than nitrogen atoms [47]. Furthermore, the $\mathrm{U}-\mathrm{O}_{\mathrm{pyr}}$ length and $\mathrm{U}-\mathrm{O}_{\text {carb }}$, [(U-O1 and $\left.\mathrm{U}-\mathrm{O} 5\right]$, are relatively greater than the axial oxygen's [U-O11 and U-O12] due to overlap between the $6 \mathrm{~d}$ and $5 \mathrm{f}$ orbitals of the uranium atom and three $\mathrm{p}$ orbitals (or two $\mathrm{p}$ and one hybrid $\mathrm{sp}$ orbitals) of each axial oxygen giving the linear structure. The bond angles around U(VI) in equatorial plane agree with a slightly distorted pentagonal bipyramidal structure. The calculated energy, heat of formation and the dipole moment found in Table 5 .

\section{Charge distribution analysis}

The charge distribution analysis on the optimized geometry configuration of MOX and its complexes was made on the basis of natural population analysis (NPA). The data obtained indicated that the MOX molecule have a net negative and a positive pole as a result the molecule is a slightly weak dipole, $\mu=4.35 \mathrm{D}$. The charge density for the MOX and its complexes showed a relatively high charge density on the metal ions in the complexes. The negative charge is delocalized on the donating sites $\mathrm{O} 1$ and $\mathrm{O} 5$ of the MOX and N7 and N10 of Phen. The carbons, $\mathrm{C} 2$ and $\mathrm{C} 4$ attached to oxygen atoms of MOX and C8 and C9 attached to nitrogen atoms of Phen have more positive values due to electronegative character of oxygen and nitrogen atoms. The charge density in studied complexes varies from 0.165 on the Pd(II) to 0.897 on the U(VI). These results mean that there is an electron back-donation in all studied complexes except Pd(II) ion [48], from the metal to the $\pi^{*}$ orbitals of the MOX and/or Phen. This conclusion is further confirmed by comparing the values of the calculated charge density on the donating atoms, (nitrogen and oxygen atoms). The distribution of atomic charges is also important in the determination of the direction of the dipole moment vector in the complexes which depends on the centers of negative and positive charges.

\section{Molecular orbitals}

Molecular orbitals play an important role in the electric properties, as well as in UV-Vis. An electronic system with smaller values of HOMO-LUMO gap should be more reactive than one 
having a greater energy gap [49]. The energy gap $\Delta \mathrm{E}$ of the studied complexes varied between 0.136 for $\mathrm{C}$ complex which more reactive and $0.192 \mathrm{eV}$ for $\mathrm{D}$ complex which less reactive, so electron movement between these orbitals could be easily occurred so that we observe a peak around $250 \mathrm{~nm}$ in the UV-Vis. spectra for all studied complexes.

The nodal properties of molecular orbitals of studied complexes are illustrative and suggest orbital delocalization, strong orbital overlap, and low number of nodal planes. These features lead to UV-Vis spectrum characterized by low energy and high intensity bands presence of charge transfer transitions. The energy difference between HOMO and LUMO (energy gap, $\Delta \mathrm{E}$ ) for all complexes varied according to the type of metal ion. All studied complexes have lower energy gap less than free ligand, so these complexes more reactive than free ligand. For MOX, the electron density of HOMO is mainly delocalized on the MOX as all except pyrrolopyridine system $(0 \%)$, methoxy group $(0 \%)$ and density localized on hydroquinoline system $(69 \%)$, while the electron density of LUMO is delocalized and spread over all atoms in MOX molecule except fluoro $(0 \%)$ and the large percent localized on hydroquinoline system $(73 \%)$. The hardness $(\eta)$ is defined as $(\eta=(I-A) / 2)$ where $I$ is the ionization energy and $A$ is the electron affinity. On the other hand, the (I-A) equals the gap between the HOMO and LUMO. Hence, the hardness of the MOX ligand and its complexes can be calculated as $(\eta=(\Delta E) / 2)$. Hard molecules have high HOMO-LUMO gap, and soft molecules have smaller HOMO-LUMO gap [50]. Additional parameters such as $\Delta \mathrm{E}$, absolute electronegativity, $\chi$, chemical potentials, $\mathrm{Pi}$, absolute hardness, $\eta$, absolute softness, $\sigma$, global electrophilicity, $\omega$, global softness, $\mathrm{S}$, and additional electronic charge, $\Delta \mathrm{N}_{\max }$, have been calculated according to the following equations:

$$
\begin{aligned}
& \Delta \mathrm{E}=\mathrm{E}_{\mathrm{LUMO}}-\mathrm{E}_{\mathrm{HOMO}} \\
& \chi=-\left(\mathrm{E}_{\mathrm{HOMO}}+\mathrm{E}_{\mathrm{LUMO}}\right) / 2 \\
& \eta=\mathrm{E}_{\mathrm{LUMO}}-\mathrm{E}_{\mathrm{HOMO}} / 2 \\
& \sigma=1 / \eta \\
& \mathrm{Pi}=-\chi \\
& \mathrm{S}=1 / 2 \eta \\
& \omega=(\mathrm{Pi})^{2} / 2 \eta \\
& \Delta \mathrm{N} \max =-\mathrm{Pi} / \eta
\end{aligned}
$$

The values of energy parameters indicate that all studied complexes are treated as soft $(\eta=$ $0.068-0.096$ ) and MOX with $\eta=0.16$ is hard, it is also that the electronic transition within the soft complexes is easy as indicated from the $\Delta \mathrm{E}$ of complexes and these values of energy gaps for complexes are in agreement with the values for stable transition metal complexes.

The electronic transition could be described as a mixed $n \rightarrow \pi^{*}$ and $\pi \rightarrow \pi^{*}$ transitions. The $\%$ contribution and the main characters of metal ions, (Y(III), $\mathrm{Zr}(\mathrm{IV}), \mathrm{Pd}(\mathrm{II}), \mathrm{La}(\mathrm{III})$ and U(VI)) and the two mixed ligands, MOX and Phen in complexes are calculated. The HOMO can perform as an electron donor and the LUMO as the electron acceptor in reaction profile. In A complex, the electron density of HOMO is localized mainly on the MOX $(100 \%)$, the large percent localized on pyrrolopyridine (83\%), also LUMO is localized only on the all atoms of Phen $(89 \%)$ with $(9 \%)$ on Y(III) ion, the electronic transition could be described as mixed $n \rightarrow \pi^{*}$ and $\pi \rightarrow \pi^{*}$ transitions within MOX and Phen. The striking feature of the studied E complex is that the HOMO orbital is localized on the coordinated ligand, whereas the LUMO is localized on uranyl ion. The band gap energy $(\triangle \mathrm{E})$ between the HOMO and LUMO orbital is found to be $0.164 \mathrm{eV}$. The energy gap is closely associated with the reactivity and stability of the executed molecule, and shows the nature of the molecule with low kinetic stability and slightly high chemical reactivity. The HOMO is localized on MOX $(100 \%)$ without any density on the Phen ligand $(0 \%)$, the LUMO is localized mainly on the U(VI) ion $(63 \%)$ with small portions on the MOX $(6 \%)$ and Phen $(21 \%)$. The MLCT can be aroused from MOX $\left(\pi^{*}\right)$ and/or Phen $\left(\pi^{*}\right)$ to U(VI). In B complex, the HOMO orbital is localized and spreading over all atoms of the MOX only $(100 \%)$, whereas the LUMO is localized on Phen (59\%), $6 \%$ on MOX and $15 \%$ on $\mathrm{Zr}(\mathrm{IV})$ which gives arise to the possibility of MLCT from Phen $\left(\pi^{*}\right)$ and/or MOX ( $\left.\pi^{*}\right)$ to $\mathrm{Zr}(\mathrm{IV})$. In C complex, the HOMO orbital is localized completely and spreading over all atoms in the Phen (61\%) and the LUMO orbital is delocalized, Phen (40\%), MOX (28\%) and Pd(II) ion (32\%), the electronic transition could be described as mixed $n \rightarrow \pi^{*}$ and $\pi \rightarrow \pi^{*}$ transitions from MOX and Phen. In D complex, the HOMO is localized mainly on MOX (100\%), while LUMO is localized only on $\operatorname{MOX}(100 \%)$. 


\section{CONCLUSION}

The Y(III), Zr(IV), Pd(II), La(III) and U(VI) complexes of MOX and Phen were synthesized and investigated by different spectroscopic techniques. The results of FT-IR revealed that MOX chelated with metal ions as neutral bidentate through oxygen of carboxylic and pyridone groups. Also, Phen chelated to the metal ions through two pyridine- $\mathrm{N}$ groups. $\mathrm{C}$ complex with smaller energy gap $\Delta \mathrm{E}(0.136 \mathrm{au})$, is more reactive than all compounds and $\mathrm{D}$ complex with higher energy gap $(0.192 \mathrm{au})$ is less reactive than others complexes. According to the value of $\eta$, the all complexes are treated as soft $(\eta=0.068-0.096)$ and MOX is hard $(\eta=0.16)$. The HOMO of all complexes is localized on MOX $(100 \%)$ without any density on the Phen $(0 \%)$ except C complex. The HOMO is localized on Phen ligand (61\%). The LUMO in E complex is localized mainly on the U(VI) ion (63\%), in the A complex localized mainly on Phen $(89 \%)$. The antimicrobial test refer that E complex recorded a significant efficiency rather than the other complexes upon the lipophilicity behaviours. The anticancer activity of the complexes showed

more active than MOX and less active than Phen against MCF-7 breast cell line and HCT-116 colon cell line.

\section{REFERENCES}

1. Mitscher, L.A. Bacterial topoisomerase inhibitors: Quinolone and pyridone antibacterial agents. Chem. Rev. 2005, 105, 559-592.

2. Turel, I. The interactions of metal ions with quinolone antibacterial agents. Coord. Chem. Rev. 2002, 232, 27-47.

3. Ruiz, M.; Perello', L.; Server-Carrio', J.; Ortiz, R.; Garcia-Granda, S.; Diaz, M.R.; Canton, E. Cinoxacin complexes with divalent metal ions. Spectroscopic characterization. Crystal structure of a new dinuclearCd(II) complex having two chelate-bridging carboxylate groups. Antibacterial studies. J. Inorg. Biochem. 1998, 69, 231-239.

4. Macias, B.; Villa, M.V.; Sastre, M.; Castineiras, A.; Borras, J. Complexes of Co(II) and $\mathrm{Zn}(\mathrm{II})$ with ofloxacin. Crystal structure of $[\mathrm{Co}(\mathrm{oflo}) 2(\mathrm{MeOH}) 2] \cdot 4 \mathrm{MeOH}$. J. Pharm. Sci. 2002, 91, 2416-2423.

5. Chohan, Z.H.; Supuran, C.T.; Scozzafava, A. Metal binding and antibacterial activity of ciprofloxacin complexes. J. Enzyme Inhib. Med. Chem. 2005, 20, 303-307.

6. Chohan, Z.H.; Pervez, H.; Rauf, A.; Supuran, C.T. Antibacterial role of $\mathrm{SO}_{4}{ }^{2-}, \mathrm{NO}_{3}{ }^{-}, \mathrm{C}_{2} \mathrm{O}_{4}{ }^{2-}$ and $\mathrm{CH}_{3} \mathrm{CO}_{2}^{-}$. Anions on $\mathrm{Cu}(\mathrm{II})$ and $\mathrm{Zn}(\mathrm{II})$ complexes of a thiadiazole-derived pyrrolyl Schiff base. Met. Based Drugs 2002, 8, 263-267.

7. Lopez-Gresa, M.P.; Ortiz, R.; Perello', L.; Latorre, J.; Liu-Gonzalez, M.; Garcia-Granda, S.; Perez-Priede, M.; Canton, E. Interactions of metal ions with two quinolone antimicrobial agents (cinoxacin and ciprofloxacin): Spectroscopic and X-ray structural characterization. Antibacterial studies. J. Inorg. Biochem. 2002, 92, 65-74.

8. Robinson, M.J.; Martin, B.A.; Gootz, T.D.; McGuirk, P.R.; Osheroff, N. Effects of novel fluoroquinolones on the catalytic activities of eukaryotic topoisomerase II: Influence of the C-8 fluorine group. Antimicrob. Agents Chemother. 1992, 36, 751-756.

9. Zhu, L.; Wang, N.; Yang, W.; Zhang, Y.; Zhao, X.; Ji, S.; Population pharmacokinetics of intravenous moxifloxacin $400 \mathrm{mg}$ once-daily dosage in infected patients. J. Infect. Chemother. 2014, 20, 621-626.

10. De Almeida, M.V.; Saraiva, M.F.; De Souza, M.V.N.; Da Costa, C.F.; Vicente, F.R.C.; Lourenco, M.C.S. Synthesis and antitubercular activity of lipophilic moxifloxacin and gatifloxacin derivatives. Bioorg. Med. Chem. Lett. 2007, 17, 5661-5664.

11. Turel, I.; Leban, I.; Bukovec, N. Crystal structure and characterization of the bismuth(III) compound with quinolone family member (ciprofloxacin). Antibacterial study. J. Inorg. Biochem. 1997, 66, 241-245.

12. Shingnapurkar, D.; Butcher, R.; Afrasiabi, Z.; Sinn, E.; Ahmed, F.; Sarkar, F.; Padhye, S. Dimeric copper-sparfloxacin conjugate having butterfly motif with antiproliferative effects against hormone independent BT20 breast cancer cell line. Inorg. Chem. Commun. 2007, 10, 459-462.

13. Li, Y.; Chai, Y.; Yuan, R.; Liang, W. Synthesis and application of a new copper(II) complex containing oflx and leof. Russ. J. Inorg. Chem. 2008, 53, 704-706. 
14. Fallik, E.; Klein, J.; Grinberg, S.; Lomaniee, E.; Lurie, S.; Lalazar, A. Effect of postharvest heat treatment of tomatoes on fruit ripening and decay caused by Botrytis cinerea. Plant Dis. 1993, 77, 985-988.

15. Yousef, T.A.; Abu El-Reash, G.M.; El-Gammal, O.A.; Ahmed, S.F. Structural, DFT and biological studies on $\mathrm{Cu}(\mathrm{II})$ complexes of semi and thiosemicarbazide ligands derived from diketohydrazide. Polyhedron 2014, 81, 749-763.

16. Saotome, K.; Morita, H.; Umeda, M. Cytotoxicity test with simplified crystal violet staining method using microtitre plates and its application to injection drugs. Toxicol. In Vitro 1989, 3, 317-321.

17. Kueng, W.; Silber, E.; Eppenberger, U. Quantification of cells cultured on 96-well plates. Anal. Biochem. 1989, 182, 16-19.

18. Geary, W.J. The use of conductivity measurements in organic solvents for the characterization of coordination compounds. Coord. Chem. Rev. 1971, 7, 81-122.

19. Patel, M.N.; Dosi, P.A.; Bhatt, B.S. Square planar palladium(II) complexes of bipyridines: Synthesis, characterization, and biological studies. J. Coord. Chem. 2012, 65, 3833-3844.

20. Yadav, S.; Singh, R.V. Ferrocenyl-substituted Schiff base complexes of boron: Synthesis, structural, physico-chemical and biochemical aspects. Spectrochim. Acta Part A 2011, 78, 298-306.

21. Sadeek, S.A.; Teleb, S.M.; Refat, M.S.; Elmosallamy, M.A.F. Preparation, thermal and vibrational studies of $\mathrm{UO}_{2}($ acac-o-phdn $)(\mathrm{L})\left(\mathrm{L}=\mathrm{H}_{2} \mathrm{O}\right.$, py, DMF and $\left.\mathrm{Et}_{3} \mathrm{~N}\right)$. J. Coord. Chem. 2005, 58, 1077-1085.

22. Nour, E.M.; Alnaimi, I.S.; Alem, N.A. Spectroscopic studies on the uranyl-Schiff base solid complex (N,N'-p-phenylenebis(salicylideneiminato) $\mathrm{UO}_{2}$ ). J. Phys. Chem. Solids 1992, 53, 197-201.

23. Vieira, L.M.M.; De Almeida, M.V.; De Abreu, H.A.; Duarte, H.A.; Grazul, R.M.; Fontes, A.P.S. Platinum(II) complexes with fluoroquinolones: Synthesis and characterization of unusual metal-piperazine chelates. Inorg. Chim. Acta 2009, 362, 2060-2064.

24. Efthimiadou, E.K. Katsaros, N. Karaliota, A. Psomas, G. Synthesis, characterization, antibacterial activity, and interaction with DNA of the vanadyl-enrofloxacin complex. Bioorg. Med. Chem. Lett. 2007, 17, 1238-1242.

25. Hassan, W.M.I.; Badawy, M.A.; Mohamed, G.G.; Moustafa, H.; Elramly, S. Synthesis, spectroscopic, thermal and DFT calculations of 2-(3-amino-2-hydrazono-4-oxothiazolidin-5yl) acetic acid binuclear metal complexes. Spectrochim. Acta Part A 2013, 111, 169-177.

26. Sadeek, S.A.; EL-Shwiniy, W.H. Preparation, structure and microbial evaluation of metal complexes of the second generation quinolone antibacterial drug lomefloxacin. J. Mol. Struct. 2010, 981, 130-138.

27. Mcglynn, S.P.; Smith, J.K.; Neely, W.C. electronic structure, spectra, and magnetic properties of oxycations. III. Ligation effects on the infrared spectrum of the uranyl ion. $J$. Chem. Phys. 1961, 35, 105-116.

28. Bennett, M.A.; Robertson, G.B.; Rokicki, A.; Wickramasinghe, W.A. Synthesis, X-ray structural analysis, and thermal decomposition of the platinum(II) carboxylic acid (hydroxycarbonyl) trans- $\mathrm{Pt}\left(\mathrm{CO}_{2} \mathrm{H}\right)\left(\mathrm{C}_{6} \mathrm{H}_{5}\right)\left(\mathrm{PEt}_{3}\right)_{2}$. Formation of a diplatinum(II) complex containing carbon dioxide. J. Am. Chem. Soc. 1988, 110, 7098-7105.

29. Sultana, N.; Naz, A.; Arayne, M.S.; Mesaik, M.A. Synthesis, characterization, antibacterial, antifungal and immunomodulating activities of gatifloxacin-metal complexes. J. Mol. Struct. 2010, 969, 17-24.

30. Pasomas, G.; Tarushi, A. Efthimiadou, E.K. Synthesis, characterization and DNA-binding of the mononuclear dioxouranium(VI) complex with ciprofloxacin. Polyhedron 2008, 27, 133138.

31. Drevensêk, P.; Kosmrlj, J.; Giester, G.; Skauge, T.; Sletten, E.; Sepcìc, K.; Turel, I. X-Ray crystallographic, NMR and antimicrobial activity studies of magnesium complexes of fluoroquinolones - racemic ofloxacin and itsS-form, levofloxacin. J. Inorg. Biochem. 2006, 100, 1755-1763.

32. Gamil, M.A.; Sadeek, S.A.; Zordok, W.A.; El-Shwiniy, W.H. Spectroscopic, DFT modeling and biological study of some new mixed ligand metal complexes derived from gatifloxacin and pregabalin. J. Mol. Struct. 2020, 1209, 127941.

33. Skauge, T.; Turel, I.; Sletten, E. Interaction between ciprofloxacin and DNA mediated by $\mathrm{Mg}^{2+}$-ions. Inorg. Chim. Acta 2002, 339, 239-247. 
34. Al Omari, M.M.H.; Jaafari, D.S.; Al-Sou'od, K.A.; Badwan, A.A. Moxifloxacin Hydrochloride in Profiles of Drug Substances, Excipients, and Related Methodology, Vol. 39, Brittain, H.G. (Ed.), Burlington: Academic Press; 2014; p 299.

35. Ringer, A.L.; Sherrill, C.D.; King, R.A.; Crawford, T.D. Low-lying singlet excited states of isocyanogen. Int. J. Quant. Chem. 2008, 108, 1137-1140.

36. Coats, A.W.; Redfern, J.P. Kinetic parameters from thermogravimetric data. Nature 1964, 201, 68-69.

37. Horowitz, H.H.; Metzger, G. A new analysis of thermogravimetric traces. Anal. Chem. 1963, 35, 1464-1468.

38. Sengupta, S.K.; Pandey, O.P.; Srivastava, B.K.; Sharma, V.K. Synthesis, structural and biochemical aspects of titanocene and zirconocene chelates of acetylferrocenylthiosemicarbazones. Trans. Met. Chem. 1998, 23, 349-353.

39. Feio, M.J.; Sousa, I.; Ferreira, M.; Cunha-Silva, L.; Saraiva, R.G.; Queirós, C.; Alexandre, J.G.; Claro, V.; Mendes, A.; Ortiz, R.; Lopes, S.; Amaral, A.L.; Lino, J.; Fernandes, P.; Silva, A.J.; Moutinho, L.; De Castro, B.; Pereira, E.; Perelló, L.; Gameiro, P. Fluoroquinolone-metal complexes: A route to counteract bacterial resistance. J. Inorg. Biochem. 2014, 138, 129-143.

40. Frisch, M.J.; Trucks, G.W.; Schlegel, H.B.; Scuseria, G.E.; Robb, M.A.; Cheeseman, J.R.; Zakrzewski, V.G.; Montgomery, J.A.; Stratmann, R.E.; Burant, J.C.; Dapprich, S.; Millam, J.M.; Daniels, A.D.; Kudin, K.N.; Strain, M.C.; Farkas, O.; Tomasi, J.; Barone, V.; Cossi, M.; Cammi, R.; Mennucci, B.; Pomelli, C.; Adamo, C.; Clifford, S.; Ochterski, J.; Petersson, G.A.; Ayala, P.Y.; Cui, Q.; Morokuma, K.; Malick, D.K.; Rabuck, A.D.; Raghavachari, K.; Foresman, J.B.; Cioslowski, J.; Ortiz, J.V.; Stefanov, B.B.; Liu, G.; Liashenko, A.; Piskorz, P.; Komaromi, I.; Gomperts, R.; Martin, R.L.; Fox, D.J.; Keith, T.; Al-Laham, M.A.; Peng, C.Y.; Nanayakkara, A.; Gonzalez, C.; Challacombe, M.; Gill, P.M.W.; Johnson, B.; Chen, W.; Wong, M.W.; Andres, J.L.; Gonzalez, C.; Head-Gordon, M.; Replogle, E.S.; Pople, J.A. Gaussian 98, Revision A.6, Gaussian, Inc. : Pittsburgh PA; 1998.

41. Bergner, A.; Dolg, M.; Kuechle, W.; Stoll, H.; Preuss, H. Ab initio energy-adjusted pseudopotentials for elements of groups 13-17. Mol. Phys. 1993, 80, 1431-1441.

42. Cai, M.; Chen, J.; Taha, M. Synthesis, structures and antibacterial activities of two complexes of yttrium (III) with 2,6-pyridinedicarboxylate. Inorg. Chem. Commun. 2010, 13, 199-202.

43. Karunarathne, M.C.; Baumann, J.W.; Heeg, M.J.; Martin, P.D.; Winter, C.H. Synthesis, structural characterization, and volatility evaluation of zirconium and hafnium amidate complexes. J. Organometallic Chem. 2017, 847, 204-212.

44. Moosun, S.B.; Blair, L.H.; Coles, S.J.; Bhowon, M.G.; Jhaumeer-Laulloo, S. Synthesis, crystal structure and applications of palladium thiosalicylate complexes. J. Saudi Chem. Soc. 2017, 21, 441-449.

45. Gao, X.S.; Jiang, X.; Yao, C. Two new complexes of lanthanide(III) ion with the N3O2donor Schiff base ligand: Synthesis, crystal structure, and magnetic properties. J. Mol. Struct. 2016, 1126, 275-279.

46. Azam, M.; Al-Resayes, S.I.; Alam, M.; Albaqami, N.T.M.; Park, S.; Kruszynska, A.T.; Kruszynski, R. Synthesis and structural characterization of a dimethylformamide bound dioxouranium(VI) salen based complex with propylene linkage. J. Mol. Struct. 2017, 1150, 395-403.

47. Mohamadi, M.; Ebrahimipour, S.Y.; Castro, J.; Mahani, M.T. Synthesis, characterization, crystal structure, DNA and BSA binding, molecular docking and in vitro anticancer activities of a mononuclear dioxido-uranium(VI) complex derived from a tridentate ONO aroylhydrazone. J. Photochem. Photobio., B: Bio. 2016, 158, 219-227.

48. Ebrahimipour, S.Y.; Mohamadi, M.; Mahani, M.T.; Simpson, J.; Mague, J.T.; Sheikhshoaei, I. Synthesis and structure elucidation of novel salophen-based dioxo-uranium(VI) complexes: In-vitroand in-silicostudies of their DNA/BSA-binding properties and anticancer activity. Eur. J. Med. Chem. 2017, 140, 172-186.

49. Krogmann, K. Die Kristallstruktur von $\mathrm{K}_{2}\left[\mathrm{Pd}\left(\mathrm{C}_{2} \mathrm{O}_{4}\right)_{2}\right] .4 \mathrm{H}_{2} \mathrm{O}$. Z. Anorg, Allg. Chem. 1966, 346, $188-202$.

50. Lever, A.B.P. Inorganic Spectroscopy, 2nd ed., Elsevier: Amsterdam; 1984; p 544. 